Florida International University FIU Digital Commons

9-25-2012

\title{
Egyptian Activism in the Modern Era and the Role of Information and Communication Technologies
}

Ramsey Dahab

Florida International University, dahabramsey@hotmail.com

DOI: $10.25148 /$ etd.FI12111302

Follow this and additional works at: https://digitalcommons.fiu.edu/etd

\section{Recommended Citation}

Dahab, Ramsey, "Egyptian Activism in the Modern Era and the Role of Information and Communication Technologies" (2012). FIU Electronic Theses and Dissertations. 726.

https://digitalcommons.fiu.edu/etd/726 


\title{
FLORIDA INTERNATIONAL UNIVERSITY
}

\author{
Miami, Florida
}

\section{EGYPTIAN ACTIVISM IN THE MODERN ERA AND THE ROLE OF INFORMATION AND COMMUNICATION TECHNOLOGIES}

A thesis submitted in partial fulfillment of the requirements for the degree of MASTER OF ARTS

in INTERNATIONAL STUDIES

by

Ramsey Dahab 
To: Dean Kenneth G. Furton

College of Arts and Sciences

This thesis, written by Ramsey Dahab, and entitled Egyptian Activism in the Modern Era and the Role of Information and Communication Technology, having been approved in respect to style and intellectual content, is referred to you for judgment.

We have read this thesis and recommend that it be approved.

Paul A. Kowert

Ronald W. Cox

Russell E. Lucas, Major Professor

Date of Defense: September 25, 2012

The thesis of Ramsey Dahab is approved.

$\begin{array}{r}\begin{array}{r}\text { Dean Kenneth G. Furton } \\ \text { College of Arts and Sciences }\end{array} \\ \hline \begin{array}{r}\text { Dean Lakshmi N. Reddi } \\ \text { University Graduate School }\end{array}\end{array}$

Florida International University, 2012 


\section{DEDICATION}

To My Wife and Kids 


\section{ACKNOWLEDGMENTS}

First and foremost, acknowledgement must be given to the millions of Egyptians who braved through dangers and risked their lives for justice. Freedoms in the West are often taken for granted, but after spending time in Egypt, my appreciation for the democratic values that protect expression and association were rekindled. For me, the struggles in Egypt, or for that matter any society enduring repression, serve as a constant reminder of the obligation we have as U.S. Citizens to nurture freedom in this world.

I would also like to acknowledge the constant support and guidance of my Major Professor, Dr. Lucas. Thank you, Dr. Lucas, for your patience and wisdom. Likewise, warm gratitude goes out to Dr. Cox and Dr. Kowert for serving as committee members. Your feedback was appreciated. To my colleagues in the program, your perspectives on International Relations helped forge my understanding on global policies and world events. I thank you for your contribution to my education and to this thesis. 


\section{ABSTRACT OF THE THESIS \\ EGYPTIAN ACTIVISM IN THE MODERN ERA AND THE ROLE OF \\ INFORMATION AND COMMUNICATION TECHNOLOGIES}

by

Ramsey Dahab

Florida International University, 2012

Miami, Florida

Professor Russell E. Lucas, Major Professor

How was the Mubarak regime overcome? Moreover, what role did technology play in social consolidation and mobilization in Egypt? Is this unique to 2011? This paper proposes that in Egypt, ICT socialization - meaning the process where individuals rely on technology to accommodate norms and values with behaviors that help manage one's identity_enabled a political self-awareness to occur in each cycle of change, from the Kefaya movement to the April 6th movement to the 2011 Revolution, and evolved political activism into a social force capable of organic mobilization. Accordingly, this study examines correlations among the Egyptian Movement for change, better known as Kefaya, the April 6th movement, and the Egyptian Revolution of 2011 in order to locate causality for large movement consolidation and effective political mobilization in Egypt. 


\section{TABLE OF CONTENTS}

CHAPTERS

PAGE

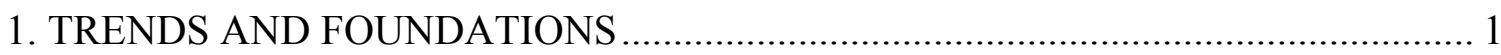

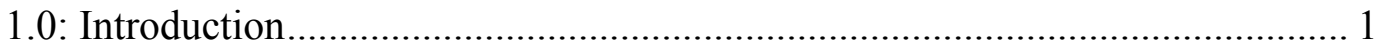

1.1: Trends Linking Activism with ICTs ......................................................... 2

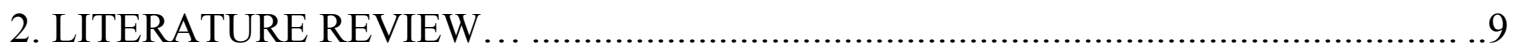

2.0: Media Effects: Delusional Optimism or Accurate Representations? .............. 9

2.1: Political Engagement \& Empowered Participation ......................................... 15

2.2: Social Movements and Revolutionary Causalities ....................................... 19

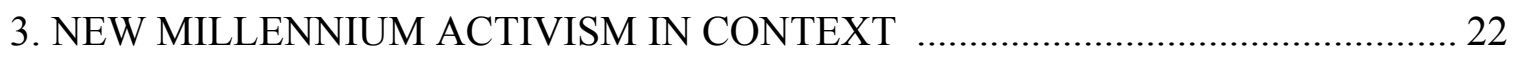

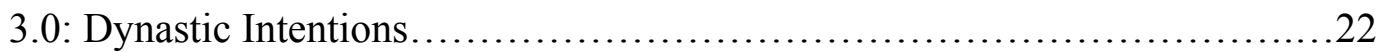

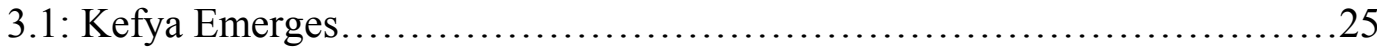

3.2: The Strategic Phase..............................................29

3.3: Tactics and Methods: Kefaya's Leaps between Interdependent Phases........ 39

3.4: Mahalla 2006 and 2007: A Second Order Change in the Commoner's

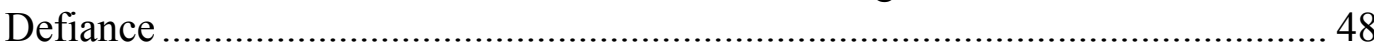

4. KEFAYA, OFFSHOOTS, AND THE EVOLUTION OF ACTIVISM IN EGYPT .... 54

4.0: Mahalla 2008: Facebook, the Unions, and Payoffs ....................................... 54

4.1: Mahalla 2009: Limitations, Regime Countermeasures, and Hollow Demands

5. EMPOWERMENT AND ENGAGEMENT: THE MANIFESTATION OF

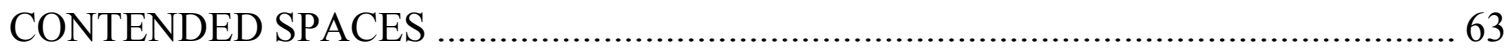

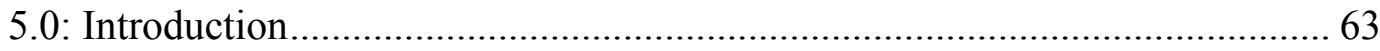



5.2: Police Brutality, Kahled Said, and Facebook Activism.................................. 69

5.3: The Breaking Point ...................................................................................... 73

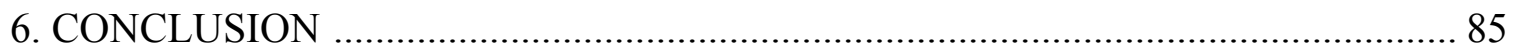

6.1: Recommendations for Further Research......................................................... 91

BIBLIOGRAPHY ........................................................error! Bookmark not defined. 


\section{LIST OF FIGURES}

FIGURES

PAGE



Figure 3.2: Cell Phone and Internet Growth, 2003-2009...........................41



Figure 3.4 and Figure 3.5: Outrage with Foreign Policy $\ldots \ldots \ldots \ldots \ldots \ldots \ldots \ldots \ldots \ldots \ldots . .50$

Figure 4.1: Wheat Price Index 2008-2010....................................60

Figure 5.1: The Silent Protest Honoring Khaled Said.............................. 72

Figure 5.2: Engagement Tactics Spread Via Emails and Flyers........................77

Figure 6.1: Info. Diffusion and Socialization Model................................87

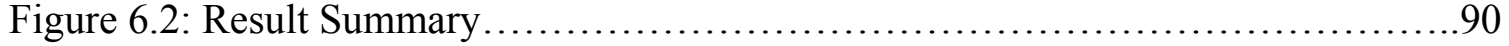




\section{CHAPTER 1}

\section{TRENDS AND FOUNDATIONS}

\section{0: Introduction}

The Mubarak regime ruled Egypt for three decades by sustaining its grip on power through a combination of social repression and political savvy. After thirty years of the regime's oppressive tactics, however, the political climate endured a radical shift in 2011, as a revolution spearheaded by an apparent youth movement utilized information and communication technologies (ICTs) — understood as any electronic or digital mechanism used primarily for the purpose of communication such as acquiring, inputting or the exchanging of information - to remove an entrenched president. But how, and more importantly, why after thirty years of oppression was the uprising finally able to consolidate and induce change? Moreover, ICTs had been utilized before. First, in 2004, a revolutionary movement named Kefaya employed ICTs to mobilize against Mubarak. Next, from 2008-2009, an offshoot of Kefaya named the April $6^{\text {th }}$ movement merged technology with labor grievances in an attempt to destabilize the regime's power. Yet, these movements failed.

Thus, the question that needs to be answered is: What changed between the periods of time that limited or enabled each movement's effectiveness? This paper proposes that in Egypt, ICT socialization-meaning the process where individuals rely on technology to accommodate norms and values with behaviors that help manage one's identity — enabled a political self-awareness to occur in each cycle of change, from the Kefaya movement to the April 6th movement to the 2011 Revolution, and evolved 
political activism into a social force capable of organic mobilization. Accordingly, this study examines correlations among the Egyptian Movement for change, better known as Kefaya, the April 6th movement, and the Egyptian Revolution of 2011 in order to locate causality for large movement consolidation and effective political mobilization in Egypt.

\section{1: Trends Linking Activism with ICTs}

Recent global trends depict a resurgence of political activism across cultures and distances, as evident by the Orange Revolution in the Ukraine (2004-2005), the Arab Spring in the Middle East (2010-2011), and the Occupy Wall Street movement in the West (2011). Despite the heterogeneous features differentiating each movement from the others, a common characteristic exists among them. In each case, ICT was utilized during political engagement as a means for combating state authority. More specifically, ICTs facilitated social relationships by organizing activities around political expressions, thereby constructing an organic campaign focused on political defiance. The networks that emerged, bonded by like-mindedness and similar values, intensified political engagement and transcended boundaries. As a result, the political efficacy of ICTs has not only become undeniable but in addition, has polarized the academic community.

While one school of thought argues that ICTs reduce the costs of political participation, thus increasing the potential for collective action, the other side of the spectrum counter-argues that ICTs bolster the Governments control over society. From this point of view, ICTs represent nothing more than mechanisms for engagement. As 
such, the dominant force will always be government power since the government not only possess the resources to institutionalize the emerging realms offered by ICTs, but also possess the capacity to "create a culture of fear and self-censorship around technology use" (Howard, 2011; p.900). However, there seems to be a consensus on at least one account. Neither view has yet to satisfy the other in explaining the 2011 Egyptian Revolution. Both polarities concede that neither view has yet to offer a profound understanding "of the process by which millions of thousands of [people in Egypt] mobilized with astounding political effect" (Morozov, 2011; p.897-898). This study attempts to reconcile the gap between the theories by studying the role of ICTs in Egypt.

As most of the world experienced the Egyptian Revolution of 2011 via ICTs, the manner in which advanced technologies and politics converged into one cohesive phenomenon suggests that the two elements are inseparable in the present context. The notion of culture clashes, elite spheres of influence, and institutional power, while serving as reference points for analysis in the Middle East, must now include the role of digital media to produce any effective theory (Howard, 2010). Moreover, since technologies exist at the frontiers of human knowledge, the constant stream of modifications and upgrades only adds to the socio-political dynamics found in countries enduring repression. In this regard, ICTs represent a necessary space, in which power is negotiated and exerted. For example, in the case of Egypt, the Mubarak regime finessed the implementation of ICTs to stimulate economic development and maintain its position at the helm of information diffusion. 
The Mubarak regime promoted itself as a modernizing government in an attempt to maintain its good standing with financial systems such as the World Bank, International Monetary Fund (IMF), and the United States Agency for International Development (USAID). It utilized the Internet to establish government websites, link investors to appropriate networks, and help tech savvy inhabitants acclimate to addendums and policy changes. More importantly, the regime privatized the budding technology sector, giving rights to various elites within the country and outside it, in order to project liberalization. Vodafone, the world's largest mobile provider and British conglomerate, won rights to establish itself in Egypt in the late nineties. Vodafone was soon followed by Mobinil, owned by France Telecom (71.25\%) and the Egyptian based Orascom Telecom, which owns the remaining 28.75\% (www.orange.com). European multi-nationals, along with a flood of new providers from the Gulf Region, have not only bolstered Egypt's status among the global-financial institutions, but in addition, have made the mobile technology common and accessible even among the urban poor and rural populations. By the turn of the century, ICTs rooted in Egypt.

Because ICTs "significantly increased the capacity of state bureaucracies, political parties, civic groups, and journalists to organize and project their ideological perspectives to the domestic and international arena," the Mubarak regime adopted its position at the helm of the developing information infrastructure in Egypt. "Such technologies are also part of the tool kit that political elites have for managing the flow of information and constructing political opinion" (Howard, 2010; p.175). Consequently, the regime's state controlled media blindly nurtured a culture of mistrust between the 
government and its society. News reports either emerged framed to fit the regime's agenda, or did not emerge at all. The framing of the news forced a tech savvy generation to trade traditional information mechanisms for ICTs in order to acquire information on political issues.

Online social networks evolved from this need and created a political culture that not only received the news in a traditional sense, but actively engaged in it as well. In some instances, users produced the news by utilizing video uploads, blogs, and YouTube to illustrate the level of corruption and tyranny inflicted by the regime. Police beatings, sexual harassment occurrences, documentations of fraud, and evidences of slander were posted and shared among the virtual communities. Political life in Egypt, in its broadest sense, had become "situated within the domain of media" (Svensson, 2011; p.109). Kefaya, the April 6th movement, and the 2011 Revolution serve as case and point.

Besides the periods representing an evolved awareness amplified by technological advances, three specific changes across these three cases help situate this study. First, the manner in which consolidation and mobilization differed in the periods remains disputed in the academic realm, thus demanding investigation into determining causes. Second, the movements made extensive use of ICTs expanding its utilization by receiving, critiquing, and creating news specifically through technology applications. Finally, since 2003 ICTs have been a dynamic resource for activist legitimization and a means for logistical coordination representing a new political frontier for political engagement (Howard, 2010; 95). As such, the case studies create robust data sets on the dynamics 
between society and institutional power as well as methods behind effective mobilization against repressive regimes. Accordingly, this study is structured as follows.

Chapters 2 and 3 help situate the framework for this study's analysis, and Chapter 4 explores Kefaya's development, achievements, and regression within a non-linear trajectory. The premise revolves around the notion that activism in Egypt occurs cyclical but with varying patterns (El-Mahdi, 2009). That is, since the 1952 Officer's revolution, the cause for dissent focused around repression (economic, political, or otherwise) and foreign policy. Kefaya's fundamental principles formulated in the seventies and disclosed in 2004 express needs similarly conveyed by Nasser during the Pan Arab movement, as well as by the Islamic movements in the 80's and 90's and the 2011 Revolutionaries. Thus, when Kefaya declares: "We believe there are two grave dangers which beset our nation today. They are two sides of the same coin...The odious assault on Arab native soil... [Intended] to recast the chart and fate of the Arab people in the region.... [And] the repressive despotism that pervades all aspects of the Egyptian political system," they are expressing recognized threats that have persisted for generations (harakamasria.org). The paradox found in Egyptian activism is that it remains retroactive. That is, problems are perceived as conditions of one's own time and existence despite their pre-existing structures (Sartre, 1957). Therefore, with causal relationships representing a constant, technological evolution may represent an underlying difference that not only affects the manner in which mobilization occurs but also may help determine a movement's effectiveness. 
The sections after Kefaya as well as Chapter 5, analyze the events leading up to the 2011 Egyptian Revolution with particular focus on ICT usage and network associations. In this section, analysis focuses on four critical events: (i) President Obama's 2009 speech in Cairo, (ii) the beating and death of Khaled Said, (iii) rising wheat prices, and (iv) the 2011 Tunisian Revolution. These events may have loosened the regime's ability to control, or for that matter, defuse the surge of activism that erupted. Finally, Chapter 6 concludes the study by gauging the similarities and differences stemming from the 2005-2011 movements as well as recommendations for future research.

Accordingly, this study will employ case studies of the Kefaya movement, the April 6th movement and the Egyptian Revolution of 2011 as points of comparisons. Economic structures and regime coalition dynamics were key causal variables in formulating revolutionary passions. However these effects were relatively constant over time and thus, represent the background of this study. Instead, this study argues that, in Egypt, ICT socialization evolved political activism into a social force capable of organic mobilization thereby, functioning more as an intervening variable. Consequently, the dependent variable is the degree of change in political activism.

This study's limitation examines only a fragment of revolutionary activity in Egypt. Nonetheless, movements since the 1950's constitute non-periodic occurrences surfacing at different points and under different banners but ultimately, functioning with the same undetermined idea for reform. The performative constant among these movements affixes social needs as consequences stemming from indiscriminate 
repression and foreign policy. However, before engaging the epistemological questions, literature on media effects and political engagement help locate the study's objectives. 


\section{CHAPTER 2}

\section{LITERATURE REVIEW}

2.0: Media Effects: Delusional Optimism or Accurate Representations?

The notion that the Media affects behavior is neither ground-breaking nor controversial. In fact, most theories these days have come to accept the idea that media content can, and often does, influence behavior. To what degree, however, is a point of contention. To illustrate, a critical dialogue played itself out in the recently published Perspectives on Politics (December, 2011).

The ensuing debate between Phillip N. Howard and Evgeny Morozov (2011) engaged the effects of ICTs, devoting specific energies to the costs of collective action. Howard begins the debate by framing his argument on the phenomena of the Arab Spring and some of its unique features. For example, the Arab Spring activists were predominately 20-30 years old, middle to upper middle class, and highly educated in regards to the standards of their respective countries. Also, these activists were politically inexperienced, lacked clear leadership and were highly collaborative by nature. Yet unlike a 'bourgeois public sphere' which is premised on the idea of a privileged few who gather to discuss and contemplate ideas that counter government rule, the youth of the Arab Spring never held a consensus of ideas as a primary objective (Habermas, 1989; p.27). Instead, they pursued what Svensson (2011) called a "Network Logic"

The concept of Network Logic incorporates ICTs' perpetual modernization as a catalyst for not only creating new niches for political participation, but also for creating 
new environments as a source for evolving political awareness. An important facet of Svensson's work (2011) captured the emergence of the like-minded people and their ability to establish a communal order via the Internet. "The main outcome of increasing socialization along the lines of like-mindedness rather than geography is unlimited access to culture and contents of all sorts. This in turn implies a different and more complex connectivity, depending to a greater extent on culture reflexivity" (Svensson, 2011; p.112). In other words, the main difference between a bourgeois public sphere and a network logic order is that the former concept is bound by geography. Network logic, on the other hand, deals more with an evolving self-awareness that explores itself unobstructed by geographical or cultural limitations. As Sartre once wrote, "In discovering my inner being I discover the other person at the same time, like a freedom placed in front of me which thinks and wills only for or against me... This is the world in which man decides what he is and what others are" (Sartre, 1957; p.38). This is the world of network logic; where self-awareness awakens the individual and socializes the user to define others. Once engaged, the user assumes a series of undertakings such as: student, browser, teacher, activist, conformist, observer, facilitator, administrator, and any other role deemed relevant for identity actualization. Thus, the user becomes a part of a network of intentions that finds commonalities in beliefs which in itself, represents a means for "becoming" rather than an ends for resolving conflicts. Morozov (2011), however, argued that because this logic was glamorized by a drove of like-minded scholars, the residual effects have created a "Kumbayah" account of how ICTs impact the world (Morozov, 2011; p. 898). To him, self-awareness and subjective awakenings have little impact on state power. 
The acclaim for ICTs is short-sighted and academically negligible. According to Morozov (2009 \& 2011), it cannot be stated enough that a number of scholars have missed the bigger picture. First, the Internet is not an un-contested space. Even from liberal and democratic societies, the state's overwhelming power to control the Internet is a fact that seems to be marginalized by the delusional euphoria induced by "democratic zealots." Just look at "Britain's attempts to control social media and any future riots [caused by the Occupy Wall Street movement] and San Francisco's decision to shut down mobile networks to disrupt [the Occupy] protests [as] cases in point" (Morozov, 2011; p.897). Second, the neo-liberal construct has positioned multinational companies in a unique position to capitalize on trade laws designed to limit state regulations. As such, some companies conduct their dealings with repressive governments in a negative fashion. That is, they assist these governments in keeping the Internet in check (Morozov, 2011). ICT filtering software, primarily from Western suppliers, help censor and monitor activities. Morozov (2009) notes that "Western companies are always happy to provide authoritarian governments with technology that can make filtering of text messages easier...IBM struck a deal with China Mobile to provide it with technology for tracking social networks and individual's messaging habits" (Morozov, 2009; p.175). Hence, the real effects of ICTs vary in their productions.

Morozov (2011) cautions the "democratic zealots" of the Arab Spring, who proclaimed ICTs as the missing link of empowerment. He warns: "Given the undeniable mobilization advantages of the mobile phone, one may start singing its praises before realizing that it has also provided the secret police with a unique way to track and even 
predict where the protests may break out" (Morozov, 2009; p.303). And in regards to the Arab Spring, he contends that in time, surviving authoritarian regimes will catch up to their neighbors, as well as in Asia, and develop efficient modes for digital surveillance. He points the democratic zealots championing ICTs to the recent developments in South Sudan.

In a report by Alan Boswell (2011) of McClatchy Newspapers, the issue of ICT and its adverse effects on political activism in South Sudan personifies Morozov's argument. Boswell writes: "Faced with a clear opening-round defeat, the [oppositional] movement [in South Sudan] is doing something that questions the assumptions about the role of social media in enabling the Arab revolts: [Rather] It's going old school, revolutionary-style, and shunning many of the technologies that are credited with mobilizing the other uprisings" (www.mcclatchydc.com, April 6, 2011). The article goes on to depict the highly effective hacking and sabotage methods employed by government officials. From bombarding Facebook pages with pornography, forcing the pages to shut down, to tracking instant messaging, to imprisoning protestors reporting on events, ICTs proved a vital resource for the government. Thus, Egypt and Tunisia may, in fact, only be an exception to a doctrine which is bound by a simple truth: Governments control Information and Communication Technologies.

Consequently, Howard's argument agreed to a certain extent that this capacity of state hegemony functions as a barrier for political activism. These barriers transform ICTs from a perceived notion of uncontested space into a panoptic realm. Yet, Howard insists that the mere vastness of cyberspace causes a high improbability for proper 
censorship to truly occur. The alternative for authoritarian governments would be to disconnect from an interconnected world experiencing technological proliferation. Iran's recent exploration into a national Internet serves as the example.

Thomas Erdbrink (2012) recently argued that the "fear that the disabling of the software that was used to bypass the state run firewalls, heralds the coming of what authorities have labeled a National Internet...Iran officials have accused U.S. based companies such as Google, Twitter, and Microsoft of working with U.S. authorities to spy [on Iran]" (as found in Miami Herald, 2/11/2012 pg. A21). As such, ICT users in Iran operate in the dark. That is, they are not only disconnected from the rest of the world but in addition, they are segregated from local connections. The Iranian regime has chosen the path of isolation rather the exposing its society to a realm of influence. Yet, in Egypt, this solution is not a viable option since links with the global economy mandates connection. However, the question that remains is: does the Internet condition or influence behavior? On this point, it becomes necessary to revisit Svensson's network logic.

Considering the same logic of cultural reflexivity for technological reflexivity, the increased use of ICTs can result in identity formation becoming highly contingent on the activity of technological engagements. Facebook and Twitter exemplify this claim. With over a billion users between them, the social networking sites represent a personalized community predicated on status updates, groupings, friends, likes and dislikes, and walls for photos and comments. These sites become a realm requiring identity formation and maintenance. A user expresses the self to the community and either contributes to the 
communal network or is relegated in status. In a sense, online social networks require active participation and thus, the habitual repetition as well as the underlying commitment to the community conditions human behavior. Moreover, the more technology engagement, the more technology socializes behavior and contributes to identity formation. According to Svensson (2011), this mode of "disciplining should thus be understood as an increasingly controlled and rationalized process of adjusting activities, communication networks, and power relations" (p.114). Information and Communication Technologies enable a collective intent to manifest, and for desires, beliefs, and values to find a common ground among individuals, groups, and organizations. Therefore, ICT socialization bridges motivations, constructs identities, and impacts the external environment in a reflexive continuum.

Within social networks lies a paradox that cuts both ways. For example, the Morozov (2011) perspective sees the issue of globalization from a top-down perspective. Thus, Facebook and Twitter as well as software developing companies like IBM can actually strengthen authoritarian power. While Howard (2011) is quick to assert that surveillance of such a vast space is not only improbable but also easily circumvented, the question of anonymity remains a delicate issue. On this point, Howard offers a slight concession by acknowledging that the business of the Internet sometimes discourages democratic potential from emerging. Both scholars point to the Facebook user agreement that stipulates any falsification of identity constitutes a direct violation of the agreement and grounds for shutting down the Facebook page. However, Facebook's regulations do not deter Howard's position since in the case of the Egyptian Revolution; such actions 
were reversed when a flood of protests pressured Facebook to ignore their own bylaws.

In the end, the debate leaves more questions than answers. The most prominent question stems from a mutual dilemma between the contending sides. What were the consolidating forces behind the mobilization of millions of protestors in Egypt? A deeper understanding on political engagement is required before attempting to answer this question.

\section{1: Political Engagement \& Empowered Participation}

When considering Verba et al.'s (1995) concepts on political culture, in which the individual assesses political engagement through a cost-benefit analysis before deciding the course of action, ICTs emerge for some, as vehicles that reduce the cost analysis of engagement. Since ICTs bridge distances, political engagements can occur internally or externally. As an example, throughout Mubarak's reign in Egypt, political oppositions from abroad sustained efforts to have their issues represented. By utilizing ICTs, they ensured presence in the Egyptian political landscape. More importantly, however, ICTs enabled the internal/external dissent to occur via blogs, webpages, and other social networking sites independent of the state. In this regard, a community developed within a virtual realm without having to physically expose oneself to danger and with the ability to screen one's identity despite the regime's monitoring ability. For those that were adept at utilizing ICT software designed to bypass state firewalls and surveillance tools, prominent status was attained. This may contribute in explaining the manner in which 
activism spread in Egypt, especially when considered alongside Howard's study on information technology in the Middle East.

Verba et al. (1995) concluded that a "strong relationship between political participation and political recruitment might result from the fact that many people get involved through close bonds with others; however it might also result from a reciprocal process by which people are asked to take part because they are already active" (Verba et al., 1995; p.158). In either case, personal relations play an important role in determining political engagement, especially when considering activity diffusion in politics. This point may reconcile the gap between political awareness and political participation, especially in repressed environments where opportunities are limited, and the state remains the dominant source for information.

Building on the concepts of Verba et al. (1995), we can add Howard's (2010) assertions on ICTs usage among friends and family members in the Middle East. From a socio-economic perspective, the notion of smart phones, personal computers, and laptops exist in scarce supply in places like Egypt. As such, ownership is shared. "Such communication technologies may be owned but not exclusively held. That is, the act of ownership is not one of monopolizing the technology from the use by others...the rules of technology ownership are that the owner has the right of first use, but also the right to see that the technology can be used by friends and family in a set of priorities that the owner gets to determine" (Howard, 2010; p.154). Relations, then, determine the manner in which the engagement finds its source and evolves networks. Charting the evolution of social networks in the Middle East proves a difficult task, but Eickelman (2005) and 
Lynch (2003) addressed the budding influence of networks well before others considered the possibility of ICT's ramifications.

Eickelman (2005) addressed the nascent social networks in an article titled "New Media in the Arab Middle East and the Emergence of Open Societies." He stated that "A public sphere is emerging throughout the region in which messages and images in the face-to-face conversations, newspapers, books, magazines, anonymous leaflets, videos, audio cassettes, satellite and regular television crisscross, overlap and build on one another. When censored or suppressed in one medium, such messages recur in another" (Eickelman, 2005; p.40). He depicted a public sphere that would evolve with technology and become network logic. Lynch (2003) also diagnosed this energy, almost a decade before it happened: "New media, including satellite television stations such as AlJazeera, Arabist and Islamist newspapers distributed free of charge on the Internet, and rapid distribution of news via e-mail, and instant messaging have given citizens in states such as Jordan, Egypt, Lebanon and throughout North Africa, the means to undermine state censorship and control" (p.56).

Brundidge and Rice (2010) contribute to the political discourse on civil society by addressing that complexities occur when interacting with ICTs. According to the authors, ICTs offered little insight into political engagement as a causality for increased participation since, political learning determined the scope of engagement. Essentially, mere exposure to content does not determine increased political involvement because intelligence ultimately dictates the degree of activism. Brundidge and Rice (2010), however, offered a narrow perspective. 
Accumulating information is in itself an activity and can become an integrated social interaction, one in which skills and perspectives on the world are shaped by those who partake in communication technology. Political socialization, as in Egypt, may occur not only through primary socialization by caregivers who define reality, and the nation-state who structures political rights, but also through political framing, as defined by those who possess technological resources. One member of a family may be able to impact an entire home, class, or group. If so, the cascade of influence spreading from a set of individuals and groups reshapes political interests and galvanizes a political culture around technological and cultural reflexivity. Simply, ICT socialization can occur vicariously through intimate bonds and associations.

"Political culture is defined by both social relationships and the material means of transmitting information about those relationships....Political culture is a set of cognitive and material schema for organizing the movement of socially significant object through scripted political process" (Howard, 2010; p.159-160). Accordingly, a political culture in a repressed environment represents a reflexive condition in which learning is conditioned and shaped by a range of political actors. In this regard, Brundidge and Rice (2010) failed to consider political engagement from a micro-perspective, one in which ICT users not only "globalize local struggles" through selective knowledge transfers, but also enable the construction of a civil society around a structured premise (Howard, 2010; Entman, 2004). Naturally, an organizational core emerges in budding civil societies. But, how does the organizational core affect the political culture in repressed areas like Egypt, especially when ICTs offer an exchange of ideas from individuals? How do loose 
associations bounded by collective intent evolve into a revolutionary force? Furthermore, how does a broad range of organizations with a broad set of interests find cohesion with other groups? Answers to the questions help locate underlying cause for revolutionary motivations and may help extract underlying patterns common to Kefaya, the April $6^{\text {th }}$ movement, and the 2011 Revolution.

\section{2: Social Movements and Revolutionary Causalities}

Theories about revolutionary causality, which is still a prominent aspect to consider while analyzing an eroded social contract between state and society, remains somewhat limited in its' explanatory capacities involving ICTs. For instance, Skocpol's (1994) structuralist perspective places relationship dynamics between state organizations and dominant class interests as the underlying conditions that launch revolutions, thereby marginalizing the role of individual actors. Her argument follows that "competition among states (including, but not limited to, warfare) has often contributed to the political crises and administrative military breakdowns that launched social revolutions....Willful individuals and acting groups may well abound in revolutions...but no single group, or organization, or individual creates a revolutionary crisis or shapes revolutionary outcome through purposive action" (Skocpol, 1994; p.8-10). Skocpol's broad perspectives may apply to some of events that are unfolding in Iran, for the simple reason that their attempts to nationalize the Internet are derived from Government relations with the West. Yet, does it help in explaining the revolution in Egypt and more specifically, it's mobilizing elements? 
Unlike Iran, Egypt was a prominent example for the neo-liberal agenda and a stout ally with the West. Foreign policy during Sadat's later years and throughout most of Mubarak's reign focused on averting economic calamities that threatened domestic institutions. By falling in line with neo-liberal guidelines, the World Bank (WB), International Monetary Fund (IMF), and USAID provided sustenance to Egypt's economy in the 1980's and 1990's. This created an enigmatic portrait of Egypt throughout the World. On the one hand, the country possessed the greatest population of Sunni Muslims in the region; while on the other, its role in the Middle East functioned to facilitate a secular agenda that not only ran counter to Islamic teachings but more importantly, enabled exploitations to occur from a broad set of accomplices. To facilitate exploitation, the regime limited social spaces in order to prevent popular uprisings (religious or otherwise). However, once technology progressed to the point where association occurred in virtual spaces, authoritarian power became diluted. The individual assumed a more prominent role in shaping, framing, and determining revolutionary activity. In lieu of technology's evolution, Skocpol's (1994) theory cannot account for the impact of virtual communities, online activists, Facebook pages, and the manner in which consolidation occurs during electronic engagement. Gurr and Goldstone (1991) also fall victim to technology’s advancements.

Gurr and Goldstone (1991) proposed political exclusion, economic integration, and fiscal crisis as the most important determinants of state-society turmoil. Furthermore, the authors claimed that when a state is preoccupied with its own selfinterests and corruption becomes wide spread, then the pending effects will lead to 
economic disparity, stagnation, or decline. Likewise, when a state is preoccupied with internal dissent or with persistent border skirmishes, it will also succumb to economic turmoil. This may help to understand facets of the Arab Spring and the Occupy Wall Street movements, since a political-economic fiber existed that not only created a wealth discrepancy, but also enabled elite structures to possess a virtual monopoly on capital wealth. Yet, the theory falls short in explaining the consolidation and mobilization elements of these movements, and specifically, the 2011 Egyptian Revolution. To clarify, one must explore beyond causality the consolidating and mobilizing factors that enabled the 2011 revolution. Further, it is required to specifically address the role of ICT during the event. Globalization may have contributed to the conditions, but it was through ICTs that problems became defined.

So why was the 2011 revolution successful and Kefaya and the April 6th movement limited? The technology was similar, as were the actors and their grievances. The purpose of this research is to answer what changed? The present paper proposes that in Egypt, ICT socialization evolved political activism into a social force capable of organic mobilization. Accordingly, this study examines correlations among the Egyptian Movement for change, better known as Kefaya, the April 6th youth movement and the Egyptian Revolution of 2011 in order to locate the causality for large movement consolidation and effective political mobilization in Egypt and to determine the role of Information and Communication Technologies. 


\section{CHAPTER 3}

\section{NEW MILLENNIUM ACTIVISM IN CONTEXT}

\section{0: Dynastic Intentions}

In order to understand complex operations in Egypt and specifically, the use of ICTs to coordinate and mobilize activism, the blanketed repression enforced by Mubarak's power triangle (the ruling party, domestic security forces, and the military) needs to be acknowledged. First, Mubarak under internal pressures from his National Democratic Party (NDP) appointed a new cabinet in 2004, which comprised of elite businessmen with limited political experience. These appointments created a stir and were widely considered as the beginning of transitional shifts from an old guard to a new one. Assuming part of the new constituency included Gamal Mubarak's ascension; the public began to wonder aloud if 2005 would be the year when Egypt's presidency officially became a dynastic rule. In any case, the appointments merged capitalism with authoritarianism and yielded a monopoly over the country's wealth. Kandil (2011) reflects on the selections:

"Mohammed Mansour, one of the biggest car dealers in Egypt, became Minister of Transport. A tycoon in the tourist industry, Zoheir Garreneh, became Minister of Tourism....The Minister of Investment, Mahmoud Mohieddin, went on to become Managing Director of the World Bank....The Minister of Finance, Youssef Boutros-Ghaly, was a senior IMF executive, and remained linked to the fund....The result was a combination of outrageous looting by these insider capitalists, and blatant neo-liberal exactions on the population" (Kandil, 2011; p.18).

The burdens imposed on the populace were extensive. Besides corporate taxes being cut in half and levied on the mass public, farm lands were privatized. 
Subsequently, land barons decimated the livelihood of farmers relying on government subsidized lands. In addition, the majority of the population endured setbacks as cost of living increases became augmented by stagnant wages. Nonetheless, it was the youth segment who felt the brunt of the regime's policies. For them, a desolate future lied ahead since unemployment within this demographic remained the highest. Each year an influx of new graduates saturated an already limited labor market. Adding to the futility, Egyptian custom requires a potential suitor to secure private residence before courtship, thereby dashing hopes for marriage and confining the growing majority of young people to their parents' residence. In all, the tolls on society were indiscriminate. Without the potential for a better future, the disenchanted became increasingly aware of the system's corrupt nature.

This is not to suggest that a sudden realization occurred in which discontent began to question institutional authority. However, the implications of such blatant corruptions and personnel setbacks created a swell of counteractions. These counteractions, or counter-thoughts, began probing for the necessary spaces required for a counter-power to emerge. Nonetheless, the biggest obstacle for such emerging disaffection was found in the security institutions designed to limit associations.

The security apparatus operated in a three-prong approach, which consisted of an intelligence agency resembling the Central Intelligence Agency (CIA), a paramilitary division protecting ministries and embassies, and a quasi-police force with ranks, divisions, and squads. Combined, they safeguarded the regime from collective actions and conditioned social behavior through intimidation. "[There were] thousands who 
[were] imprisoned and detained, [and of those] hundreds [were] tortured in police stations" (Sha'aban, 2006; p.45). The police operated under the principle that its power, its "disciplining" of citizens, was a necessary reinforcement of the state. Police power even encroached on military domains.

Infamous for its brutality, the Egyptian Police garnered international condemnation on one hand, while serving as a crucial component for the War on Terror on the other. Western countries sent prisoners to Egypt for the sole purpose of interrogation and torture. "Vincent Cannistraro, the CIA's former counterterrorism director, told Newsday about an al-Qaeda suspect taken to Egypt, 'They promptly tore his fingernails out and he started to tell things.' Former CIA agent Bob Baer told The New Statesman, 'If you want them to be tortured, you send them to Syria. If you want someone to disappear — never to see them again — you send them to Egypt,"' (Rajiva, 2005; p.1-3). The police represented a pervasive force in Egyptian life and more importantly, in the psyche of every Egyptian since the agency itself was the personification of the state in its most brutal and powerful form. Conversely, the military enjoyed a covert privilege within the country.

The military branch operated as the most complex and corrupt of all the components. Their interests existed beyond the duties of traditional military institutions. Because every Egyptian President came out of the military ranks, as well as the strong showing against Israel in 1973, the Egyptian military possessed national esteem and was a source of national pride. However, until recently, little was known about the military's vested interests in the regime's policies. With holdings in the tourism industry, beach 
front properties, hotels, jeep assembly plants, a charter airline company, as well as stakes in hospitals, gas stations, cement factories, and construction companies, the military remains embedded in the globalized Egyptian economy (Schwartz, 2011; p.36). Some accounts place the annual profits from the factories alone at $\$ 750$ million US dollars (Masoud, 2011; p.25). Other valuations estimate the military's cut of the Egyptian economy at $40 \%$. "Whatever the precise size of the military's holding, it stands to reason that it would want to protect them from grasping politicians who could be tempted to meet popular demands for redistribution by dipping to the army's coffers" (Masoud, 2011; p.26). This may explain the Army's constant existence behind the shadows as well as its hostility toward the private sector. Thus, with a society repressed and exploited emotionally, physically, and psychologically and with technology advancing at a pace sufficient to promote associations, the conditions were ripe for dissent to emerge.

\section{1: Kefaya Emerges}

Kefaya was formed during Ramadan of 2003 when a gathering of 23 activists consisting of Marxists, Nasserites, Copts, Islamists and Liberals from the 70's generation, broke bread and discussed the future of Egypt. By the end of the night, the group reached a consensus on two issues: (i) the removal of Mubarak from power and (ii) the termination on foreign dependence. Within six months of its formation and coinciding with the newly appointed Cabinet, the movement expanded its presence from the informal spaces licensed by the regime to the more expansive realms enabled by 
information and communication technologies (ICTs). Its membership grew from the original 23 members to more than 4,000 by mid-2004 (Baheyya, 2005).

Commemorating its first anniversary, Kefaya orchestrated the first ever antiMubarak protest in December, of 2004. The protest drew thousands of people from across the political spectrum, as chants of "Enough!" and "No to inherited power!" rocked the power centers in Egypt. Since then, social scientists have defined Kefaya as an ideology, a protest movement, or simply, as an identity crutch enabling expression. Different studies have given various accounts of this movement.

For instance, Monar Shorbagy (2007) refrains from labeling Kefaya as a protest movement, and instead, defines Kefaya as a socializing force whose effects continue to evolve politics in Egypt. Kefaya liberated Egyptians from psychological imprisonment and created an emblem for political sophistication. According to Shorbagy (2007), Kefaya empowered "a new generation of Egyptians [with] the promise [of] transforming politics in Egypt. They...found a home and an instrument in Kefaya, and in the process...invented a new form of politics" (Shorbagy, 2007; p.176).

Similarly, other Egyptian intellectuals and scholars labeled the movement as an awakening. According to them, Kefaya inspired a movement that incorporated grievances from all sectors in Egyptian life and embodied a modern anti-regime ideology that transcended social movement structures (Sha'ban, 2006). Well-known blogger and assumed Kefaya member, "Baheyya" (2005), captures the movement's enigmatic nature: "Defining what Kefaya is, is genuinely difficult. It fits none of the available models found in the Egyptian political landscape. It's not an 'opposition party', it's not an NGO, 
it's not a professional association, it's not a solidarity committee, it's not a party-inwaiting (like Wasat and Karama), and it's not a grassroots initiative" (Baheyya, March 2005; April Blog). According to Bahyeaa (2005), Kefaya offered self-awareness to the Egyptians and planted the seed for a political awakening. On the contrary, other studies preferred a more pragmatic approach for analysis.

Scholars with opposing viewpoints (Hamzawy, 2005; El-Mahdy, 2009; Bush, 2010) argued that Kefaya must be observed as a protest movement since repression created it. Hamzawy (2005) argues that this repression "reinvented the street as an arena for political action" (Hamzawy, 2005; p.4). Organizations, resource managements, and locations were crucial in Kefaya's defiance. In fact, most protests occurred in, or near, urban centers making industry and state institutions the primary object, thereby, limiting the participation to urban dwellers. Thus, the terms "broad" and "encompassing" are not accurate representations of Kefaya. These perspectives focused on Kefaya's structural strengths and limitations. Moreover, these scholars argued that the movement's inability to present a clear identity caused the group to collapse.

Following this further, Ray Bush (2010) tracked the complex undercurrents responsible for waves of protest in Egypt from 2006-2008. His study avoided stigmas and figurative ambiguities assigned by Egyptian scholars and journalists and instead, focused on economic difficulties and the effects unique to Egypt's political landscape. Bush located Kefaya as a class struggle waged between the middle class and the ruling elite, thus, marginalizing $80 \%$ of the population (the poor and extremely impoverished). According to him, Kefaya, in the absence of these relevant participants, "offered a 
structural weakness that limited its political muscle", and therefore, the movement's demise was inevitable (Bush, 2010; p.124). In totality, these perspectives confound Kefaya's contributions to Egyptian politics since the conclusions of various studies clash, and appear dislocated and contradictory. They dictate a re-thinking of Kefaya's efficacy in Egyptian politics.

The present study proposes that Kefaya's existence was, and is, predicated on performance. First, the basic tenet of the movement is in itself a performative speech act. Kefaya!, meaning Enough! in Arabic, "produces certain consequential effects upon the feelings, thoughts or actions" of Egyptian activists and their fellow compatriots (Austin, 1962; p.101-103). Kefaya! constitutes a maxim and invokes a spirit of defiance. Accordingly, it occupies abstract properties as defined by Shorbagy (2007) and Baheyya (2005). Yet at the same time, all movements are legitimized by action and therefore, require events that present the movement as a counter-force to the populace at large. Events, in turn, require organization and tend to produce goals and objectives. As such, Kefaya can be measured empirically by its achievements and limitations. This fact coincides with Hamzawy (2005) and Bush (2010) and compels any analysis on Kefaya to include structural, economic, and participatory factors.

Accordingly, the following section explores Kefaya's transformations in the figurative and literal realms. The study suggests that Kefaya transformed in phases, which consisted of a: strategic, tactical, and method phase. Framing Kefaya's activities within this paradigm identifies the hybrid ideology recognized by Shorbagy (2007) and 
"Baheyya" (2005), as well as the distinct social movement features documented by Hamzawy (2005), El-Mahdy (2009), and Bush (2010).

Essentially, this study argues that Kefaya experienced organic growth between the virtual and physical world, and as a result, developed in non-linear transformations. In both realms, reflexivity - the circular relationship between cause and effect in which change bends back on initiating causes creating a second order change (a progressive or regressive reorganization)—occurred. Moreover, the use of technology augmented spaces, issues, and motivations for this movement. Kefaya transformed protest behavior, traditionally linked to social, economic, and political issues — which include civil rights, health care, education, unemployment, wages, housing, and general cost of living —into a resistance determined to undermine the regime. Its structural facilities are revealed through the complex networks formed and the enduring legacy left on Egyptian activism. ICTs role throughout the processes served as the binding thread in which contexts merged and affiliations found synergy.

\subsection{The Strategic Phase}

Information and Communication Technologies offer a space in which environments, realities, and experiences transcend boundaries and reconcile distances. This fact not only bridged Kefaya with domestic actors, reducing costs for political participation, but also, bridged the movement internationally, expanding the knowledge of strategists. The focus for now remains on the latter connection. 
The initial conditions that formed the core were purely domestic realities.

However, the strategies employed were distinctly linked to international experiences and research. "Indeed, according to some accounts, Kefaya was inspired by 'peaceful civil revolutions in the West that led to political change, namely the Orange Revolution in Ukraine," the Rose revolution in Georgia, and the Serbian revolution of 2000 (Khalil, 2005 as found in Oweidat et.al, 2008; p.20). Additionally, the genealogy of the strategies linking the European movements can be traced back further to Gene Sharp's pamphlet (1993) - From Dictatorship To Democracy, a quasi-handbook for social movements premised on years of revolutionary studies. Precedence along with a grounded theory on activism helped Kefaya to form a grand strategy for action.

To be clear, Kefaya did not start because of East European movements (20002004) or Sharp (1993), nor are any of Kefaya's successes attributed to anyone or anything other than the participants involved. Yet, external support provided a relevant experience that helped identify and adapt the regime's countermeasures. Srdja Popovich, one of the leaders of the Otpor movement (Serbia, 2000) and head of the Center for Applied Nonviolent Action and Strategies, admitted: "You can't import or export revolution, it has to be homegrown. But what we can do is build skills and help. Sometimes it takes time; sometimes you know it isn't going to work straight away. But there are always things you can do" (Peter Apps, 2011; p.2). From 2005-2011, Popovich and Peter Ackerman, a student of Gene Sharp, held workshops for non-violent revolutionaries in Europe, Asia, and the Middle East, and also in Egypt (Shishkin, 2008; p.2-3 ). Although specific accounts on when and where activists from Egypt interacted 
with Ackerman or Popovich remain difficult to chronicle (or for that matter any other outside force aiding activist development) there can be some degree of certainty that Kefaya members studied the conceptual frameworks of other movements. To understand the manner in which techniques were interpreted from these movements requires us to examine the command flows within Kefaya.

Kefaya was not an organization, yet it did contain structural elements. First, much like the East European movements the core of seven members represented a quasiboard of directors in which a consensus had to be reached for important decisions. From the core, three positions were designated to sustain viability. George Ishaq, a secularist and communist Copt, was named the movement's coordinator and managed daily operations. Abd al-Halim Qandil, editor of the Al-Arabi newspaper and Nasserite, served as the movement's spokesperson, and Malik Mustafa handled the technology division serving as the movement's webmaster, Blog writer, and technologies expert (Irsherwood, 2008; 4; Oweidat et.al., 2008; p.11). Together, the leadership provided a tacit vision of political reforms without any impositions of rules or regulations. More importantly, the absence of hierarchies, created a symbiotic movement that channeled energies rather than delegated duties.

Kefaya was a fluid movement and the logic behind this loose structure protected it both internally and externally. Meaning if leadership was compromised, the movement would still survive since dependence existed beyond charismatic personality or particular intellects. In this sense, Shorbagy's (2007) figurative claim resonates, since it can be argued that Kefaya was an idea imposed on repression rather than a model that fit into 
social movement theory or organization theory. In addition, a benefit found in Kefaya's loose structures was the ability to absorb members. In other words, some members brought blogs with them, some computer proficiency, while others brought syndicate affiliations and union connections. Much like the Otopr strategy in Serbia (2000), Kefaya refused to become a political party and instead, created a "network of local, independent [Kefaya] chapters with no central committee or spokesperson. Their intention was to create a broad based movement and to have so many layers of leadership that it would be impossible to arrest them all" (Braxton, 2006; p.9). And despite most members belonging to political parties, all respected the Kefaya ideal and left their party affiliations outside the movement's doors (Shorbagy, 2007). Fluidity safeguarded against movement hijacking. Studying the East European movement bore fruit since the acquired approaches helped formulate strategies, tactics, and methods for engagement. Strategies like non-violent defiance and movement branding could be implemented with relative ease and fluidity as each component helped create momentum in Kefaya's initial launch. In short, history provided Kefaya with a road map for defiance.

\section{The Non-Violence Component}

According to Sharp (1993), a non-violent struggle "is fought by psychological, social, economic, and political weapons applied by the population and the institutions of the society" (Sharp, 1993; 30). By utilizing protests, strikes, boycotts, and disaffection, power flux destabilizes the regime's control and emphasizes the brutality used to quell non-violent defiance. Therefore, it is in the interests of authoritarian regimes and dictators 
for activists to initiate violence, since "even limited violence during a political defiance campaign will be counterproductive, for it will shift the struggle to one in which the dictators have an overwhelming advantage" (Sharp, 1993; p.32). In Egypt, Kefaya kept a strategic eye on opportunities for engagement, specifically in the intangible realms (psychological and ideological) dominated by the regime.

In February, 2005, President Mubarak arrested Ayman Nour, an Egyptian politician planning to run in the Presidential election later that year. A backlash of international outrage caused the then U.S. Secretary of State, Condoleezza Rice, to cancel her trip to Cairo. Furthermore, the White House intensified its pressure on Mubarak for more democratization (Radwan, 2005; p.1). Two months later, the Egyptian parliament passed a referendum on article 76 , making it appear as if elections would be open to multiple parties, provided that a candidate received support from 250 elected politicians. Kefaya protested against the charade.

On May 25, 2005, a peaceful demonstration confronted plain clothed police officers as well as regular forces, and endured beatings, arrests, and humiliations. Within hours, the international media picked up images and news accounts from bloggers, Baheyya and Wael Abbas, as well as from journalists, Noha El Hennawy and Hassan M Fattah, whose account of the story appeared in the New York Times the next day (Baheyya, 2005; Abbas, 2005; Hennawy and Fattah, May 26, 2005; p.1-3). The backlash of negative press forced the regime into a more tolerant position on protests. The impact was immediate, as the next week thousands of demonstrators protested the arrests made on May twenty fifth. The protest occurred without incident. As international and 
domestic pressures squeezed the regime to create a second order change in which taboos were overcome, political defiance reclaimed social spaces once forbidden. Kefaya had won a major victory.

What non-violent defiance helped create on May $25^{\text {th }}, 2005$ was a paradox for the regime. On the one hand, sanctions served the regime's self-interests domestically and reinforced the psychological dominance over its society while on the other; the regime's brutality tarnished its international standing with key trading partners like the United Staes. As Skocpol (1994) argued, international pressure affects political crisis and as a result, determines the spaces required for revolutionary activity. Taken further, we may add Goldstone and Gurr (1991) who offer political exclusion as an explicit example of a contested space. According to them, a contested political space demystifies authority causing a crisis to emerge. Basically, "state crises are...crises of legitimacy" (Goldstone and Gurr, 1991; 331). What remains unaccounted for from these frameworks is the impact of technology, and more specifically, technology as a means for network formation and social consolidation in Egypt.

Information and Communication Technologies, from its initial implementation, provided a crucial component that has not been documented by scholars, journalists, or activists thus far. Essentially, ICTs laid the foundation for historical documentation of all activities. Being able to bypass the state's monopoly over information empowered activism with a new type of influence and endowed it with a power to shape historical content that not only ran counter to the regime's account but more importantly, framed narratives to fit its own agenda. Furthermore, it archived protests, articles, and fallouts 
for all actors involved. Each historical event that commenced became a part of an evolutionary tract that enabled defiance. Users were historians and bound together events, and placed them in the memories of other users (Hegel, 1988; p.4). A synthesis occurred between the street and consciousness, which not only broke psychological barriers but also, enabled Kefaya to brand itself. The next three months averaged more than a protest a week and encompassed an array of participants ranging from mothers to youths to professionals and from bloggers to the unemployed, each protesting specific contentions (see Figure 3.1). Yet in all, the link to despotism and its histories created an issues spiral that connected Kefaya-to protestors-to contending spaces-and ultimately-to the regime.

Figure 3.1: Kefaya Related Protests in the Summer of 2005

\begin{tabular}{|c|}
\hline Summer of 2005 \\
\hline $\begin{array}{l}\circ \text { June } 1^{\text {st }}-\text { Egyptian Mothers protests against security harassment } \\
\circ \text { June } 9^{\text {th }}-\text { "The Street is Ours" protest calling for more women's rights } \\
\circ \text { June } 15^{\text {th }}-\text { Youths for Change and bloggers demonstration } \\
\circ \text { June } 22^{\text {nd }}-\text { "Freedom Now" Protest } \\
\circ \text { June } 26^{\text {th }}-\text { Demonstration in front of Ministry of Interior against torture } \\
\circ \text { June } 29^{\text {th }}-\text { Demonstration at the Virgin Mary Church to show consolidation } \\
\text { between faiths }\end{array}$ \\
\hline $\begin{array}{l}\circ \text { July } 14^{\text {th }}-\text { Unemployment Protest } \\
\circ \underline{\text { July } 20^{\text {th }}-} \quad \underline{5,000 \text { protestors rally to support Judges opposing election }} \\
\text { monitoring policies } \\
\circ \text { July } 31^{\text {st }} \quad \text { Protest against Upcoming Elections }\end{array}$ \\
\hline
\end{tabular}




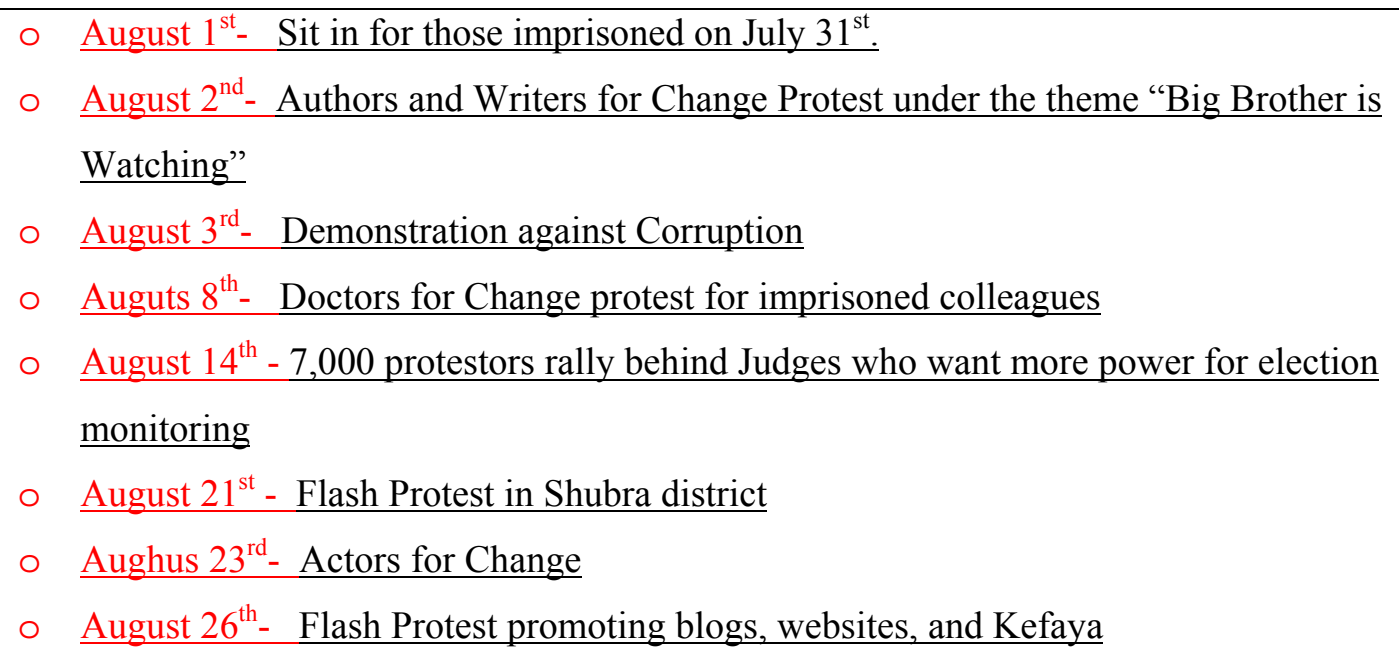

Branding Kefaya

Slogans and symbols provided Kefaya with implicit communications to an entire population, particularly the urban poor. Banners, graffiti tags, and bumper stickers were tagged on: walls, inside public bathrooms, trains, light-poles, underneath highways, on pavements, and on market carts. Flash protests lasting 20 to 30 minutes passed out thousands of flyers with information about pending activities, or in other instances, the basic tenets of the movement (El-Mahdi, 2009; p.90-91). Assemblies at universities recruited new members. Each campaign waged and every initiative launched appealed to people's subjective will (passions and desires) and rational will (social justice and freedom) in attempt to subvert the regime's role (Hegel, 1988; p.41). 
This strategy served two purposes: first, it relegated the regime to an abstract idea that was contingent on the will of the people thereby, liberating psychological barriers even further; and second, it elevated Kefaya as the vessel in which liberation could be attained. Through aggressive branding, the movement bridged perception with literal acts of defiance. The brand itself became a symbol of a "conscious will" that represented a demand for change. Each banner, each posting, each graffiti tag simultaneously engaged the physical and cognitive elements of defiance. By targeting impoverished areas, Kefaya pursued the disgruntled by promoting self-awareness. They promoted an ideal that contrasted "the way things are with the way things ought to be," and focused on the need for change as its guiding principles (Hegel, 1988; p.37). Consequently, brand recognition spread and "change" became a calling card for activism. The potential for what ought to be became a purpose of many. Once again, Shorbagy (2007) and Baheyya's notion of Kefaya as a psychological liberator resonates. However, the diffusion of its ideal and the manner in which offshoots were organized are facts more in line with Hamzawy (2005) and Bush (2010).

Kefaya franchised the slogan "Change" and by mid-2005, the movement possessed loose affiliations and representations in 24 of the 26 provinces in Egypt. It successfully mobilized almost every major profession including but not limited to: Professors for Change, Judges for Change, Youths for Change, Engineers for Change, Journalists for Change, Lawyers for Change, Doctors for Change, and Authors and Actors for Change (Oweidat et, al., 2008; p.18-19). With networks spread across 
locations and industries, ICTs disseminated information designed to inspire, convince and persuade users, as well as link the street to the entire country.

According to a mission statement posted on its website along with a 242 page report titled, "Towards a New Social Contract", a vision for change demanded an end to corruption, emergency laws, unchecked political system, and a limit on the Presidential terms. It also covered humanitarian rights, and political freedoms that addressed democratic governance. Generally, the narratives engaged users' subjectivity and linked anti-regime sentiments to a network of like-minded people. Combined with the ability to document the spirit of the time as well as the reclaiming of social spaces, Kefaya's strategy was prepared to sever the regimes authority (Shorbagy, 2007; p.191).

Kefaya's integrated strategy began socializing segments of the population. That is, while ICTs helped coordinate activity and helped persuade users' thoughts and actions, engagement also occurred via traditional grass roots campaigns. By combining the two modes, political learning was enhanced. As seen later, the groundwork laid by Kefaya helped establish a growing self-awareness among the masses. Thus, while Brundidge and Rice's (2010) study finds little correlation between ICTs and expanded political activism, Kefaya helps reconcile the manner in which a political culture began emerging in Egypt. Through branding, non-violent defiance, and historical framing, Kefaya's strategies set a course for action in which ICTs played a pivotal role in defining meaning. 


\section{3: Tactics and Methods: Kefaya's Leaps between Interdependent Phases}

The difference between tactics and methods can be clearly understood once both the terms have been defined. Tactics are premised on strategies and available resources implemented for a limited period of time. In this paper, tactics relate to resources used for mobilization and socialization, such as text messages used for triggering flash protests, blogs on specific topics or events, or social networks like Facebook which crystalized around methods. Methods refer to specific means of actions such as labor strikes, policy protests, themed demonstrations, and boycotts (Sharp, 1993; p. 45). The convergence of tactics and methods aided Kefaya's coordination and removed organizational structures, particularly in virtual spaces.

The first element in this section locates ICTs within the socioeconomic divide in Egypt. Accordingly, blogs, text messaging, and the Internet are waged against technologies' availability and accessibility in order to determine the extent of content diffusion that socialized the general public. The second element examines phaselocking - the coordinated and synchronized actions among members or groups around specific methods. Phase-locking between tactics and methods evolved collective action but the questions that still need to be answered are: How effective was phase-locking during Kefaya's peak period? What role did ICTs play in Kefaya's tactical engagements? Did phase-locking destabilize the regime's grip on vital resources (natural or financial) and intensify disobedience across provinces? How did the regime's response affect the bonds forged between Kefaya and groups or syndicates? The analysis begins with ICTs penetration in Egypt during the new millennium. 


\section{Tactical Engagement: The Role of ICTs}

Access to information, generally, helps one possess knowledge and, consequently, power. Conversely, people in repressed societies, as in Egypt, are forced to endure life with limited exposure to information along with limited social contacts. For many years, Egyptians could only access information filtered through governmental channels. Textbooks reinforced authoritarianism, the Ministry of Information edited media, and security mechanisms limited social affiliations, creating a grand design for socialization. Clearly, this showed that thoughts were being limited. However, technological advancements and aggressive neo-liberal policies enhanced information flows, specifically in the new millennium; yet, ICTs' capacities for expanding social spaces were either miscalculated or relegated to the periphery as the power centers were more interested in economic gains. The repercussions nurtured a virtual civil society.

The ruling elite's preoccupation with market gains overshadowed ICT's potential for communal networks. This ran counter to most authoritarian policies in the World. For example, in China, Internet monitoring software enables the streamlining of surveillance measures by relieving human resources, thus, helping agents to concentrate on other crucial factors intended to limit social consolidation. "Saudi Arabia [on the other hand] has prominent civil society groups but, [the] ruling elites have built a distinct culture of technology use," while in Iran, the Government has periodically shut down communication access entirely (Howard, 2011; 900; Erdbrink, 2012; p.22A). As of 2003, Egypt lagged behind other authoritarian regimes and "had no formal mechanisms to control and filter Internet content" (Boas and Kalathil, 2003; 122). With 70\% 
ownership in TE Data, the country's largest Internet service provider (ISP), and with well positioned elites on the board of Mobinil, one of the world's largest mobile suppliers, the regime intensified the National Project for Technology, initially launched in 1999, and "set itself a course of using [ICT] as a way to streamline and improve government efficiency, as well as to attract international capital" (Wheeler, 203; 631; Faris, 2010; 65; Freedom House, 2011; 2). Consequently, the fertile Egyptian market led to exponential growth in mobile and Internet users from 2003-2009 as shown in Figure 3.2, which depicts the growth rate in both sectors.

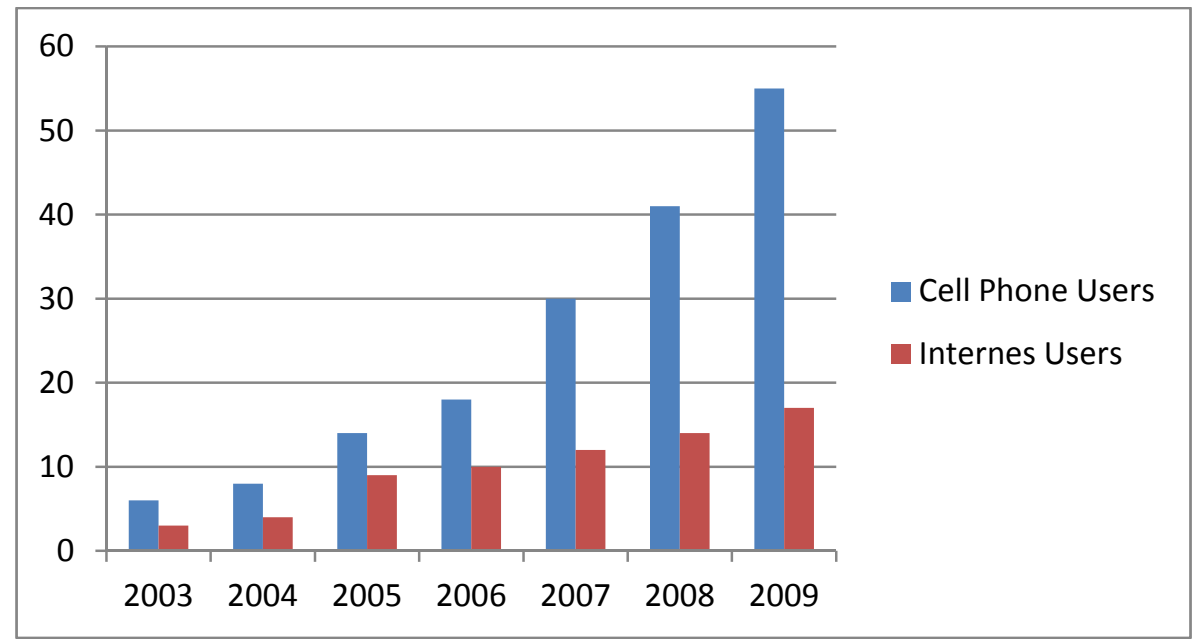

Figure 3.2: Egypt's Cell Phone and Internet Growth (in millions): 2003-2009 World Bank accessed10/04/2011—URL: http://worldbank.org/ddp/html-jsp/view/NewReport.jsp?IS

During Kefaya's peak (2004-2006), the Internet sector had approximately 8\% (over 6 million users) market penetration while mobile technology garnered almost 15\% (over 11 million users) penetration. Moreover, ISP providers were abundant and despite 
Broadband Internet access being expensive, Internet cafes were common even in urban slums and small villages (Freedom House, 2011; 1-2).

"Indeed, age, gender, education, and wealth are all important factors in determining who has [Internet] access in Egypt, but none of them are straightforward, linear relationships. The Internet privileges the young because they have been socialized into computer usage in a way their elders were not....With the spread of Internet cafes, wealth in particular, is not a huge barrier" (Irshwood, 2008; 2-3). In addition, the younger generation's affinity for technology fits into neoliberal designs, as Government programs promoted computer literacy and consumption "through programs such as the 'Free Internet Initiative in 2002' and 'A PC for Each House in 2004'” (Eid, Gamal ed., 2006; 136). Likewise, blogs became a byproduct of the open door policies and the surging political activism.

It is important to note here, that ICTs did not evolve the urge or produce the desire for civil liberties in Egypt. That claim would be an endeavor in futility and more importantly, would defy the inherent inclinations for freedom within all individuals. Naturally, this is understood as freedoms existing within the confines of an actualized social contract between state and society in which limitations exist for the betterment of society at large, rather than a select few. Nonetheless, in Egypt, the concept of freedom conflicted with despotism and caused conflicts between the subjective and objective realms. Sartre (1957) clarifies this point when he states: "In wanting freedom we discover that it depends entirely on the freedom of others and that the freedom of others depends on ours" (p.46). From this reflexive axiom, the understanding that ICTs enabled activism 
to surge can be interpreted as a choice to fulfill subjective and rational will through, and only through, collective liberation. Digital activism became an obligation for the ICTsocialized youth in Egypt because it constituted the only space in which political association could occur without exposing oneself to overt danger.

The organic and interdependent relationship between Kefaya and its first generation bloggers was a mode for tactical engagement (Lynch, 2007; Isherwood, 2008; 2). During 2005-2008, online accounts varied on the number of blogs in the Arab blogosphere; some were estimated to be around 24,000, while others estimated it to be closer to 160,000 (Isherwood, 2008; Etling et al., 2009; Freedom House, 2011). In either case, an Internet culture began relying on ICTs for social connections and more importantly, for information. Historical and political framing became points of contestation as bloggers produced, exposed, and framed news that ran counter to the regime's agenda. Moreover, new age activism and the ability to shoot videos via mobile technology elevated defiance and caused the virtual realms to experience a similar type of second order change that physical spaces experienced in 2005. Spaces, virtual or otherwise, became hotly contested spheres between the regime and the activists.

The Mubarak regime tried to hone in the technology explosion by regulating all Internet Service Providers (ISPs) and cell phone communications via the National Telecommunications Regulatory Authority (NTRA), which included representatives from the Ministry of Interior, the Presidency, the Military, and the economic sectors (Freedom House, 2011; 3). In addition, the General Administration for Information and Documentation (GAID) and the Department for Confronting Computer and Internet 
Crime (DCCIC) utilized constitutional law 147 (a press law) to come down against bloggers under the pretext of slander. By 2007, the regime hinged the emergency law to counterterrorism laws creating a blanket of surveillance that extended to all. However, the mere vastness of cyberspace made it improbable for proper censorship to have truly occurred (Howard, 2010). The pending results created ICT socialization or a set of disciplined behaviors among ICT users in which digital network connections regulated identity that extended beyond geographical and cultural influences (Svensson, 2011).

Repression was not only reported and documented, but also video-taped and shared via blogs, YouTube, and emails. There were over 2,000 blogs that linked to YouTube, which coincidentally represented the number one out-link in Egypt (Etling, et, al., 2009; 39). YouTube videos like the "The Pasha's Daughter is Terrifying People on the Street" or a segment depicting the inside of an Egyptian Prison, as well as a clip on police cruelty in which police wager on whose blow has the greatest effect on a defenseless man were linked by blogs about corruption and shared with the world (Etling, et, al., 2009; 41-42).

Blogs linked to YouTube, local news media, Kefaya's website, and international outlets, reconstituted the way news was transmitted. Activists engaged in news production as opposed to passively receiving news and in turn, began affecting traditional media. State controlled media began running editorials that countered claims or accounts made by bloggers and in some instances, were forced to report on news traditionally concealed. For instance, in 2007, blogger Wael Abbas won the prestigious Knight International Journalism Award for his documentation of police brutality 
(http://misrdigital.blogspirit.com). The video upload from Abbas's blog of two police officers beating and raping a mini-bus driver served as the incriminating evidence in the trial. Both police officers were found guilty and were sentenced to prison. In addition to Abbas, bloggers carried various banners calling for a prohibition against hereditary rule, the release of Kefaya activists, and the enforcement of anti-torture laws....Other banners called for the release of Ayman Nour" (Oweidat et al., 2008; 21). Bloggers became activists and activists became bloggers, and most of them covered Kefaya's activities, posted notifications for causes and protests, called attention to wrong doings by the government, and countered the state media. Blogging was instrumental in demystifying the regime and in the creation of corruption archives.

Blogs have served as a resource for exposing brutality and have also proved instrumental in promoting events, reporting on protests, and shaping agendas. Bloggers such as Abbas, Baheyya, The Sand Monkey, and Wahda Masrya (United Egypt) have attained celebrity status among Internet surfers in Egypt. While some of the more popular bloggers have reported to have about 300,000 visitors per month on their blogs, Abbas claimed over 500,000 visits in just two days after he reported the 25th of May protest in which the police assaulted demonstrators (Isrshwood, 2008; 3). Consequently, ICTs and their users became vital resources for Kefaya.

Kefaya advertised events via its blog networks and sent emails to members to disseminate tactical plans. It also utilized mobile technology to mobilize action. Text messages helped draw 2,000 activists to a June 2005 demonstration (Oweidat, et al., 2008; 21). In addition, text messaging informed activists of road blocks, police presence, 
tactical changes, and ongoing happenings. Mobile technology bolstered collective activity and group formation capabilities by simultaneously reducing the costs for political engagement and transforming users into digital historians - representation of events by individuals who are directly present in the spirit of the time and the process in which those events are archived within cyberspace (Hegel, 1988). In sum, the speed in which diffusion could occur was a tactical advantage for activists and created a dynamic in which street activity and online activity created a reflexivity that not only enhanced activism in Egypt but did so at the expense of the crony capitalism directing regime policies. Activism found synergy with technology and was fast becoming an extension of a user's identity.

\section{A Convergence between Tactics and Method}

Kefaya developed its brand, diffused its message, and incorporated professional syndicates; however, it remained confined to the middle-class. Until 2006, participants in most protests hovered between the hundreds and thousands. However, a combination of certain external forces and domestic realties created an opportunity for Kefaya to not only expand people's participation in it but also to link various issues across the socioeconomic spectrum.

"The policy framework of the Mubarak regime is based on selective choice of free-market principles without concern for social welfare or political reform in the interests of the mass of Egyptians" (El-Naggar, 2009; p. 36). Mubarak's neo-liberal 
cabinet produced a crisis in which monopolies, tax burdens, unemployment, and privatized farm lands decimated the already struggling poor. Egypt's gross domestic product (GDP) grew, foreign investments increased, but wages remained relatively unchanged as did unemployment consistent at 25\% in 2006 (El-Naggar, 2009; p.41-42). Moreover, rising food prices, specifically that of wheat when Egypt is the world's largest wheat importer, made lives of lower-income families unbearable. Figure 3.3 shows the increase in wheat prices by more than 30\% during 2005-2006 and by $250 \%$ during 2005 2007. According to the United Nations (U.N.), "expenditure on basic foodstuffs and services for the average Egyptian household [rose] by some 50 percent" in 2006 (Morrow and al-Omarni, 2008; p.1). Consequently, Kefaya possessed an opportunity to advance the cause for change by linking these economic grievances to broader political issues.

Figure 3.3: Wheat Price Index 05-07'

\section{Wheat Prices per ton in U.S. \$}

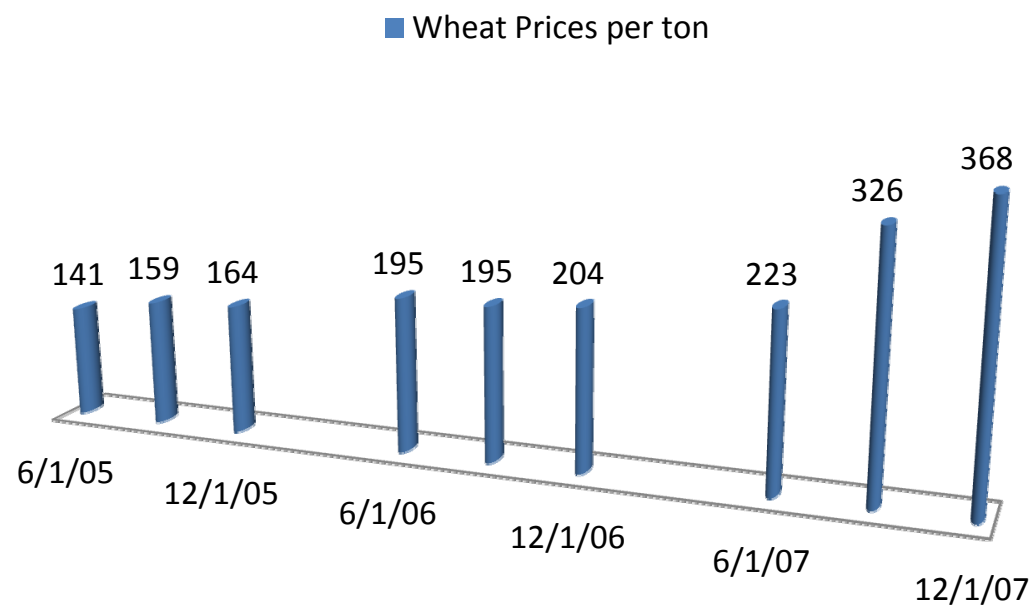

Figure 3.3: Wheat Price Index 05-07' Source: IMF. Primary Commodity Prices. URL: $\mathrm{http}: / / \mathrm{www} . \mathrm{imf}$. org/external/np/res/commod/index.asp. 
According to Beinin (2009), Kefaya's emergence correlated with the largest strike wave that Egypt had witnessed "in over a half a century. Over 1.2 million workers and their families engaged in some form of action in the context of political ferment that began with a taboo-breaking demonstration in December 2004 organized by Kefaya" (Beinin, 2009; p. 77). The largest and most politically charged of these protests took place at a textile factory in Mahalla al-Kubra in 2006, 2007, and 2008. Kefaya and Mahalla redefined the way unions operated, how the Government responded to activism, and the manner in which phase-locking occurred.

\section{4: Mahalla 2006 and 2007: A Second Order Change in the Commoner's Defiance}

After enduring setbacks at the end of 2005, Kefaya seemed to regress. From September, 2005 to the end of the year, very few protests were held. Blogs shifted attentions to human rights violations and international events dominated by U.S. and Israeli policies. Mubarak's uncontested re-election disenchanted weekend warrior activists as well as the silent majority keeping tabs on Kefaya's progress. Nonetheless, Kefaya endured regressive growth as concerns for individual safety took precedence. In the summer of 2006, Israel invaded Lebanon and accordingly, political attention shifted from domestic concerns to regional issues and from democratic demands to religious conflicts.

Kefaya, in tune with the public, implemented a tactical campaign against Egypt's foreign policy by linking the Mubarak dynasty to the U.S. and Israeli agenda. Bloggers 
attempted to enlighten the public. Baheyaa (2006) wrote: "In fact, the Israeli destruction of Lebanon (and the American destruction of Iraq before it) offers quite an opportunity for Gamal Hosni Mubarak to further insinuate himself into Egyptian public life. He can "express solidarity" all he likes and at the same time emphasize the fait accompli of his public, political role" (Baheyya, July 2006). Abbas (2006), on the other hand, captured the fervor of Egyptians on what they perceived as Arab victimization (Figures 3.4 and Figure 3.5). Yet, other groups like the Muslim Brotherhood possessed more organizational experience with issues critiquing Israeli and U.S. foreign policies.

Kefaya, for the first time was confronted with an organizational challenge that it was not structured to deal with. In other words, a movement based on loose affiliations became vulnerable to issues concerning identity. Thus, an Israeli attack on Lebanon conjured a confluence of issues. From the emotional, intellectual, and religious concerns to the political, organizational, and tactical matters, Kefaya's diverse members pulled the movement in many directions. So much so, that the leadership core set mundane agendas in an attempt to hold the movement together. 
Figure 3.4: Outrage with Foreign Policy

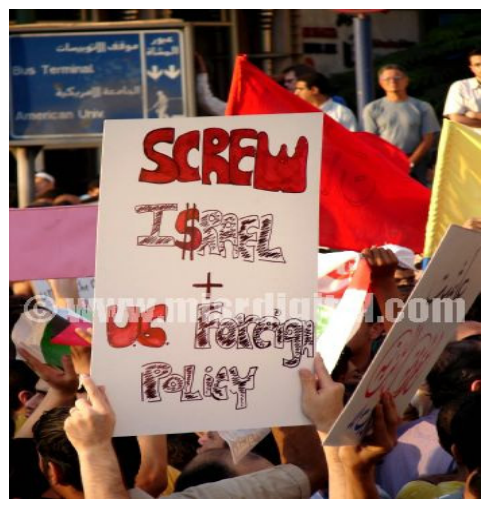

Figure 3.5: Outrage with Foreign Policy

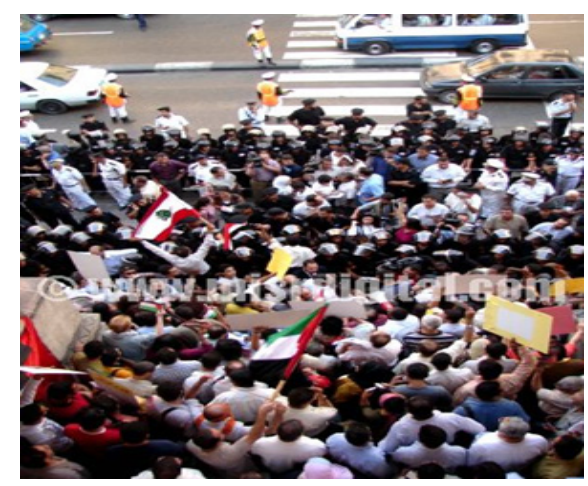

Source Wael Abbas (July 2006 blog) URL: http://misrdigital.blogspirit.com/archive/2006/07/index.html

For example, The World Cup of 2006 became one such issue. While trying to encompass the passions of the Egyptian populace, Kefaya promoted a boycott against the ART cable channel for issues regarding the World Cup and the fees associated with its broadcast. However, the cause reflected the movement's limitations on addressing foreign policy and as a result, witnessed the Muslim Brotherhood capitalize on U.S. and Israeli actions. Kefaya was in desperate need of a galvanizing issue unique to Egypt yet distinct from religious concerns and thus, it targeted the country's economy.

Kefaya utilized blogging networks and syndicates in industrial zones to launch a hybrid ICT/grass roots campaign in areas such as Alexandria, Islamia, Shubra, and Mahalla. During the winter of 2006, workers from Misr Spinning and Weaving Textile Factory demanded bonus money owed to them. The director of the company refused to acknowledge any debt and as a result, tensions grew. Kefaya's youth network stepped in and began an Internet campaign on behalf of the workers, linking grievances within a political framework. "A wide-ranged manifesto was assembled that went beyond calls 
for a reduction in food price and improved wages to the need for conditions that would help freedom and dignity and an end to arbitrary arrests, police torture and 'the manipulation of the judiciary"” (Bush, 2010; p. 125).

On December, 2006, after a month of aggressive organization, emails, and text messaging, 20,000 workers went on strike despite repeated pleas by Union leaders to avoid confrontation. After four days of escalating participation and resounding determination, the Government conceded and offered 45 days of bonus money, profit sharing structures, and assurances for better work conditions. The strike was terminated, and Kefaya's youth network as well as the workers had won a monumental victory. Information and Communication Technolgy tacticians advertised the victories and began a public campaign against shady Union leaders. Baheyaa devoted most of his late December postings lambasting the Union leadership:

"Over the past 15 years, the industrial labor force has been squeezed by soaring costs of living and unfair work conditions without a corresponding increase in official tolerance for worker collective action (much less collective bargaining). The rotten labor aristocracy that is the Egyptian Trade Union Federation (ETUF) has given up all pretense of worker representation and has instead embraced its role as first and foremost a state adjunct that polices workers and quashes any bottom-up attempts at independent representation. (http://baheyya.blogspot.com Dec/2006).

Within a few weeks, ten mills experienced similar strikes and most of them won concessions. "Workers in an Italian-owned cement factory quadrupled their salaries...thirty five thousand tax assessors duplicated the cement workers' victory, achieving a 325-percent pay raise; tobacco workers quickly won shorter hours, higher pay and less oppressive working conditions; and Suez workers reversed the firing of two 
union activists" (Schwartz, 2011; p. 37). In addition, workers from across industries began impeaching Union leaders and called for elections, women consolidated and set up their own committees, and Kefaya helped coordinate most of these efforts (Beinin, 2009).

In 2007, different labor actions, ranging from factory workers to mid-level management, occurred. With wheat prices surpassing critical points (over $\$ 350$ per ton), protests crept into all levels, including the upper management. Almost 600 different labor actions were taken that year, which ranged from "industrial worker to white-collar employees, including an incredible strike in December 2007 of 55,000 local government tax collectors" (Bush, 2010; p. 125). Kefaya's offshoots harnessed labors' vigor into effective mobilization and action. Moreover, 2007 also witnessed another strike at Misr Spinning and Weaving.

The second strike was premised on the same grievances as before, i.e., unpaid bonuses and general costs of living. Unlike the first strike, the second strike lasted only six day. The Government stepped in and offered concession of 70 days bonus money and the dismissal of upper management. However, the six day strike triggered a bigger uprising from the city's town folk a few months later, and for the first time, Facebook appeared as a mobilizing force in Egyptian politics (Bush, 2010). A youth delegate representing Kefaya embarked on Mahalla for a third time, but in this instance, would emerge as the April $6^{\text {th }}$ youth movement, fragmenting Kefaya even further.

Because Kefaya was left reeling after the 2005 elections from the inability to remove Mubarak from power, Kefaya's offshoots distanced themselves from the movement and the disenchantment from its perceived failures. These offshoots proved 
successful at phase-locking (the coordinated and synchronized actions among members or groups) political issues with labor grievances and thus, formed their own banner and operated with their own tactics. The success of 2006 and 2007 created the April 6 movement of 2008. The call for change was no longer the franchise of the day; instead, attention had shifted to pragmatic efficacy. Bloggers also shifted their attention; some opted for Facebook while others explored a new technology called Twitter, while the remaining stopped blogging altogether. Grassroots organization was no longer the prevailing strategy of choice for activists and after April $6^{\text {th }}$, s formation; the new domain got shifted to a virtual one. 


\section{CHAPTER 4}

\section{KEFAYA, OFFSHOOTS, AND THE EVOLUTION OF ACTIVISM IN EGYPT}

4.0: Mahalla 2008: Facebook, the Unions, and Payoffs

What remains unaccounted for in most literature concerning Egyptian politics is the inter-movement years that bridged Kefaya and the Egyptian revolution. While most literatures discussed Kefaya and the Egyptian revolution of 2011 from different aspects, very few discussed the evolving trends in Egypt during 2008-2009. As seen later, the regime came down hard on activists during this time, but what needs mentioning is the shift from technology as a mode for communication to technology as a form of community. Personal relationships became metaphysical and as a result, political recruitments became enhanced by intimate bonds between the like-minded.

Accordingly, "to assess the impact of [ICTs] on collective action in Egypt, we must look at the April 6th Youth Movement, and the strikes organized on April 6th, 2008... and April 6th, 2009 - strikes that were organized in large part online and whose success or failure can tell us much about the conditions under which [ICT]-driven collective action might succeed or fail" (Faris, 2010; p.115). But in doing so, we must not lose focus that it was Kefaya that not only set the agenda but also, implemented the tactics and methods for engagement. Thus, when examining the April $6^{\text {th }}$ movement, we must keep in mind that a "second order change [occurred, in which] group members [left a] comfortable, albeit an unconscious, state... [uprooted] and then reorganized" (McCLure, 2005; p.107). April $6^{\text {th }}$ then, represents an evolved form of Kefaya that can be represented (as in various literatures) interchangeably. 
In March 2008, families in Mahalla, unable to keep up with the rising food prices contacted activists (Morrow and al-Omarani, 2008; p. 1). Within several days, representations from the town, Muslim Brotherhood constituents, labor unions, and April $6^{\text {th }}$ members hashed out tactics and methods for the movement. The strike would be promoted through social media and be accompanied by a nationwide call for economic relief and political change (Morrow and al-Omarani, 2008; p. 1).

In 2008, the April $6^{\text {th }}$ movement phase-locked with the Muslim Brotherhood (MB). The alliance represented a dramatic shift for the brotherhood, as the organization usually preferred to operate alone and within the nestled spaces afforded to them by the regime. Upon merging goals, the two organizations possessed a virtual arsenal that consisted of over 11,000 web pages in both Arabic and English and over 1,000 external links to YouTube, blogs, and various websites (Howard et al., 2011). Together, they sent out thousands of emails and text messages; but April 6th's use of Facebook dispersed information most efficiently. Within a couple of weeks, over 70,000 Facebook followers committed to the Mahalla strike by agreeing to boycott work (Faris, 2010; p. 124). The economic system was at stake for Mubarak and with only 24 hours to spare, he set out to thwart a dangerous precedent that not only had the potential to escalate across the country but threatened the material resources vital for power. Subsequently, massive police presence converged on Mahalla (Morrow and al-Omarani, 2008; p. 2-3).

Massive security presence prevented protestors from holding demonstrations on the streets, but as far as the nation-wide call was concerned, the strike turned out to be a success. Estimates put participation at about $80 \%$ as production across vital sectors 
practically ceased (Morrow and al-Omarani, 2008; p. 2). Information and Communication Technologies evolved protest as consolidation and action could not only be organized online but also executed. One of the primary shifts from 2005 to 2008 was the change in online engagement.

Facebook and Twitter evolved beyond mechanisms for mobilization and expanded the communal order of network logic. Unlike blogs, Facebook and Twitter enabled participation to flow cross-dimensionally, which in a sense evolved the digital historian to include an array of participation. That is, information was not only received but produced instantly enabling users to communicate with activists as they reported from within the trenches. Evolved technology produced a more dramatic and intimate form of communication. Further, unique content was produced and political engagement entailed vicarious experiences as users lived the spirit of the event alongside those directly present. This facet enhanced socialization while keeping the costs for participation at a minimum. Thus, the need to emotionally connect to civil engagements reflects a subjective intent that forms around social problems (Salmon, Fernandez, and Post, 2010; p. 159). There are no barriers as in blogs or T.V. which lack the interactivity between people. The result was a successful nationwide campaign the resonated with tens of thousands of people.

“The Egyptian press gave extensive coverage to both Facebook and the April 6 movement after the day's events. International press outlets also lavished attention on what everyone seemed to regard as a successful strike" (Faris, 2010; p. 120). The regime would eventually counter activists with stop-gap solutions that would delay the surge in 
the public's will-power and force activism into covert spaces within ICT's domain. Also, the regime's strategy would emphasize digital surveillance and intrusive regulations, lending credence to Morozov's (2009) claim that Government ICT utilization can be a double edged sword for activists.

4.1: Mahalla 2009: Limitations, Regime Countermeasures, and Hollow Demands

At the end of the 2008 Mahalla strike, Baheyya wrote in his blog:

"We can't judge protests by their claims, but by their indirect effects. For example, Kefaya and allied social movements demand that Mubarak step down, refrain from handing power to his son, and convoke competitive, free and fair elections. This has not happened.... Kefaya's protests increased the regime's repression of democracy-seeking coalitions and may have improved the government's capacity to throttle future such coalitions in their cradle" (Baheyya, May Blog, 2008)

Indeed, the regime's response to the 2008 phenomenon in which online activists organized a nation-wide campaign that not only paralyzed the industrial output but also, threatened the stability of Mubarak's power triangle caused an intensified crackdown on ICTs. However, what Baheyya (2208) fails to consider is the very thing that he originally credits Kefaya with in 2005. Kefaya liberated the psychological bonds imposed by the regime and created a second order change in which tangible gains were made. Spaces were opened to allow dissent to manifest and the regime was proven fallible in the economic and political spheres. Change may have been deterred but the potential for it still existed. The regime recognized this reality. 
Thus, shortly after the 2008 Strike, the regime took action. First, on May 12, 2008 TE-Data restricted access to Kefaya's website. Second, all Internet cafes and access points offering wireless connection were required to conduct an intake of its users - basically, a form detailing name, address (email and home), and mobile number (Mehanna, 2010; 205-206). Third, prosecution of Internet activist intensified. The arrests of Mohammed Adel and Ahmed Maher, as well as the kidnapping of Esraa Add El Fatah, all founders of the April $6^{\text {th }}$ movement serve as case and point (Faris, 2010; p. 124126). The regime also invoked press law 147 and arrested Wael Abbas, sentencing him to six months in prison for slander. Last, the Government clamped down on Mobile technology by periodically disabling text messaging. However, in all, the regime's countermeasures did little to sway the April $6^{\text {th }}$ movement's resolve to orchestrate an anniversary protest on April 6, 2009 in Mahalla.

Using similar technologies as in the previous year, which included Facebook, Twitter, and text-messaging, the April $6^{\text {th }}$ movement began promoting an anniversary strike. Through ICTs the following demands diffused: the institution of a national minimum wage, the dissolution of parliament followed by new elections and constitutional reform, the suspension of gas exports to Israel, and "indexing prices to inflation" (Faris, 2010; 130). Still, commitment levels were hard to gauge.

By this time the regime anticipated another cycle of protests. Thus, while a core of activists possessed the resolve to endure harassment and perform in risk-taking activities, the vast majority of ICT users, including past supporters, weighed the costs for engagement. And while Facebook lowered the costs for political participation, the 
regime's crackdown on activists resonated louder among the masses than the issues calling for engagement. In this case, the hollow demands did not resonate with the vast majority and as a result, April, $6^{\text {th }}, 2009$ never materialized.

Three primary reasons for this failure are attributed to a combination of regime tactics, economic improvements, and gross oversights by the activists. First, in a preemptive strike, the regime paid off crucial segments of labor which severely inhibited the phase-locking abilities between online and offline activists (Faris, 2010; p. 130). In addition, the government blocked all text messaging capabilities for that day. Second, wheat prices decreased more than one-third from the previous year's prices (see Figure 4.1). Together with increased wages, families were better off economically than before. Moreover, the regime had established a precedence with meeting the burdens of wheat prices and inflation through concessions. Thus, while wheat prices may have been a contributing determinant for dissent, it was easily reconciled by subsidies and salary increases. Finally, "because the regime so successfully abrupted the day's event, which had been telegraphed and publicized by opposition forces months in advance, this left activists essentially with no capabilities to execute or alter their plans after it became clear that the state was ready for them" (Faris, 2010; p.133). Even more damaging than the inability to adapt, was the inability to mobilize. 
Figure 4.1: Wheat Price Index 2008-2010

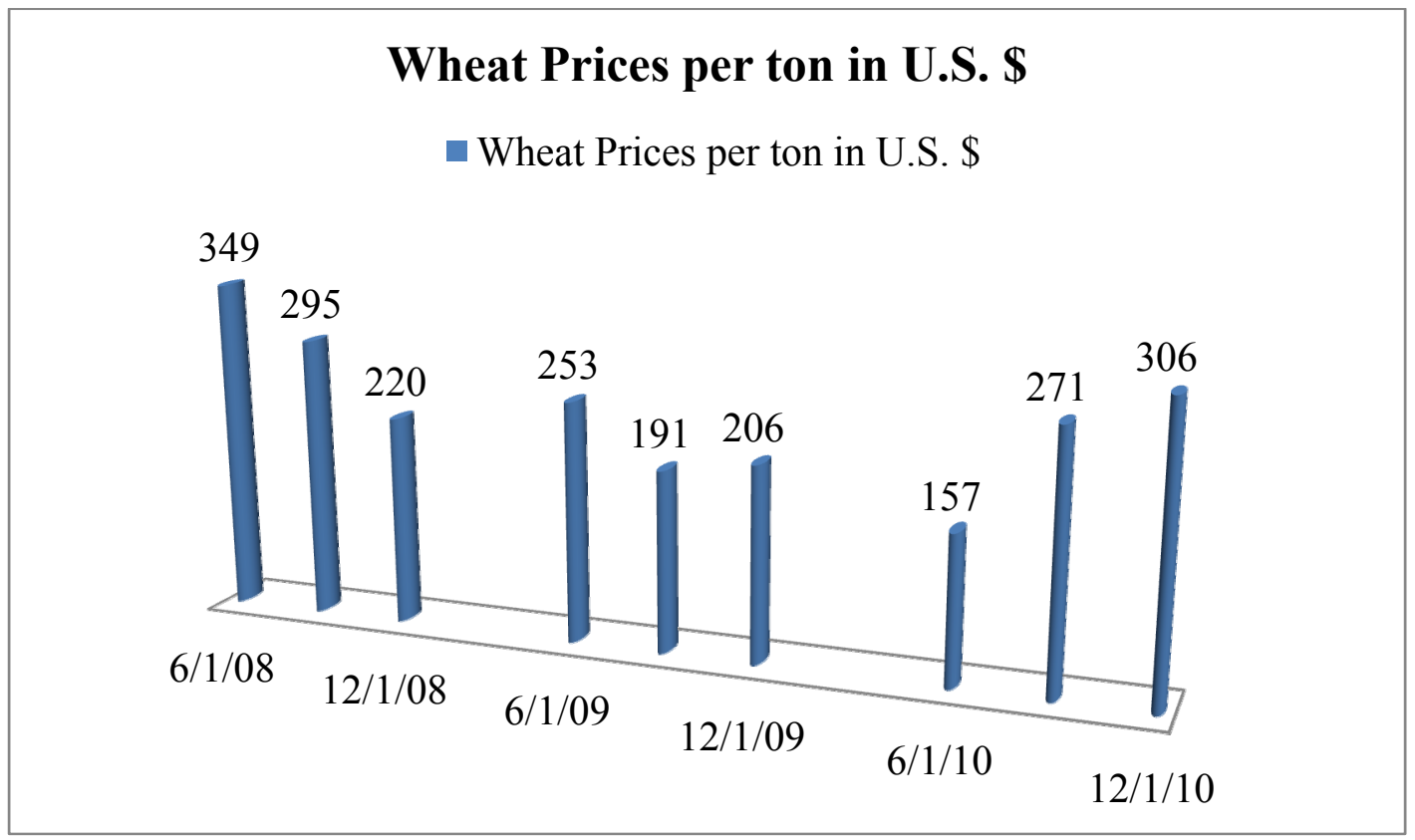

Figure 4.1: Wheat Price Index 2008-2010' Source: IMF. Primary Commodity Prices. URL: http://www.imf.org/external/np/res/commod/index.asp.

As evident from the previous years, the brunt of the oppositional forces was borne by labor. In each case, their grievances were tethered to broad political issues such as foreign policy or domestic corruption. Yet, in 2009, the activists overlooked this crucial facet to phase-locking interests. Protests, strikes, boycotts, and other methods require burdens to be shared. However, in 2009 the issues failed to connect. For example, emphasizing gas exports to Israel did little to entice the $\mathrm{MB}$, and in like manner, the call for a national minimum wage could not inspire an already exhausted labor force from ignoring certain improvements. Thus, the Mosorov argument represents a dominant facet in the 2009 Mahalla strike, but it was the inability of activists to find a theme or an issue to hinge the public's will that was the biggest failure. Sharp (1993) cautioned "as the 
long-term struggle develops beyond the initial strategies into more ambits and advanced phases, the strategist will need to calculate how the dictators' sources of power can be further restricted. The aim would be to use popular non-cooperation to create a new more advantageous strategic situation for the democratic forces" (Sharp, 1993; p.62). In 2009, the April 6th youth movement failed to ground their call for protest around a crystalizing problem, thus emboldening Government repressions and regressing the social spaces needed for activism to thrive. So how are we to assess ICT's efficacy when comparing the Mahalla Strike of 2008 and 2009?

Up to this point much has been made about ICT's impact on the subjective and rational will of activists, and for that matter, society at large. Because ICTs enabled a counter narrative to emerge, socialization was no longer a monopoly held by the regime. Through Kefaya and up to the April $6^{\text {th }}$ movement, the concept of digital historian evolved into a budding network logic predicated on like-mindedness. However, while the perception of ICTs has been that it impacts the metaphysical, it is an embodiment of material essence as well.

ICTs exist as mechanical, digital, and electronic devices which operate in a similar manner as a body. Accordingly, energy inputted produces a desired result. Feed the body and motion can be attained; fuel the automobile and potential energy can be converted. For ICTs, this energy can be interpreted as electrical power. However, in all the examples energy needs to be acted on to produce kinetic force. For instance, the body requires intent (passions, desires, motives, etc...) to produce motion, whereas the automobile involves a complex set of actions that begin with a driver's intent. Thus, in 
intent we find a dynamic source for action, and in passion we find intent in its most concentrated form. As Hegel wrote, "Nothing great has been accomplished in the world without passion" (Hegel, 1988; p.26). In order for ICTs to enable consolidation, passion is required for risk taking performance. This was evident in 2005 with crystallization around the removal of an entrenched President and opposition to hereditary rule, and was also evident in 2006-2008 when phase-locks between activism and unions crystalized around labor grievances. However, in 2009, the combination of physical obstacles imposed by the regime (café intakes, text messaging shut downs, and strategic arrests) and empty demands, produced an unwillingness to partake in risk. Thus, while ICT socialization enables change to occur, passion is required for risk-taking performance. The ability to influence is most effective when it inspires. 


\section{CHAPTER 5}

\section{EMPOWERMENT AND ENGAGEMENT: THE MANIFESTATION OF CONTENDED SPACES}

\section{0: Introduction}

After wheat prices stabilized and labor strikes were reconciled, activism was fragmented in Egypt, bolstering regime ambitions. The economy was holding steady, despite the recessions inflicting the Western economies. Tourism in Egypt enjoyed the benefits of an Arab populace disenchanted with Lebanon's instabilities as well as from the rest of the World's travelers who remained drawn to the antiquities nestled in the country. Turkish investments in the textile industry took advantage of the land incentives offered by the Government, as well as the "10 year no tax" benefit for foreign investments. Further, the Qiz agreement among Egypt-Israel-and the U.S. that ensures duty free exports for ready-made garments to the U.S, helped draw companies from across the globe, including the U.S. In fact, output in the textile industry enjoyed a $10 \%$ hike from the end of the 2008 Mahalla protest to the end of the third quarter in 2009 (www.qizegypt.gov.eg). The failed Mahalla Strike of 2009 only seemed to validate Mubarak's power triangle. However, monumental events, which consisted of President Obama's speech in Cairo in 2009, the brutal death of Khaled Said in the summer of 2010, rising wheat prices at the end of 2010, and finally, the upheaval in Tunisia, would loosen the regime's ability to control, or for that matter, defuse the surge of inspired activism that erupted in 2011 of January. The first of these events occurred during the regime's re-found dominance over its populace. On June 4, 2009, President Obama visited Egypt. 


\section{1: Obama Reactivates Defiance in Egypt}

For over two years, President Barak Obama campaigned under the slogans "Change We Can Believe In" and "Change We Need" (Hoppock, 2008; p. 1). The campaign captured the growing contempt the U.S. populace had with the status quo. From grievances with the economy and security strategies to foreign policies and political apathy, the then Senator Obama reinvigorated the general mood of voters. In a historic victory, Americans mobilized at the voting booths and collectively chose change. Six months later, and after swearing in to office as the 44th U.S. President, Barak Obama visited Egypt and addressed an audience at Cairo University. The title of the speech was “A New Beginning” (www.whitehouse.gov).

Taken in a figurative context, the historic significance of an American President addressing a dominant Muslim populace at a time when two American military occupations, as well as an ambiguous War on Terror, have specifically targeted Muslims, is, undeniably, a landmark occasion. However, considering the speech for its literal worth, little was achieved in addressing the real issues on the minds of Egyptians, and in particular, issues on democracy and human rights. Ironically, the hollow words echoed at Cairo University rekindled political defiance in Egypt's blogosphere, and when linked with the 2009 eruption of student protestors in Iran, activism was reinvigorated in Egypt. Below, the samples of blogs from Wael Abbas, the SandMonkey, and Baheyya depict the revived defiance. Wael Abbas (2008) wrote and commented to various international media such as BBC and French News.

To the BBC: "Obama should make a statement to a free Muslim country ... Egypt is not a free Muslim country. It's devastating that a man like Obama 
is coming to Egypt to reinforce the oppressive policies of President Hosni Mubarak. It's like beating eighteen million Egyptians over the head - like saying we believe in democracy but not here....To the Le Monde French newspaper, Abbas stated: "He was addressing Muslim religious sentiment, quoting the Koran; it's the same approach as the Muslim Brotherhood. He should address reason not emotions" (misrdigital.blogspirit.com, June Blog, 2009).

SandMonkey (2009), on the other hand, appealed to the ordinary ICT users and attempted to capture the futility plaguing activism in Egypt. However, the irony in his attempt was that once he and his colleagues (re)acknowledged the very problems plaguing civil society, activism surged. In totality, the responses to SandMonkey's posts on Obama's speech represented the highest comment tallies on his blog up until that point. An expert from one post about President Obama's speech reads:

"The people liked it, and Facebook and twitter are nuts with the Obama love comments. The man did a good job appeasing the Islamic world, and that's really what the people who voted for him wanted, right? That's why the section on human rights in his speech was the weakest, because let's face it, he ain't going to push on human rights and democracy. That era is gone. We are all about diplomacy and friendship now, and that's what the American people want, even if the price is that the democracy activists in Egypt gets [screwed]" (www.sandmonkey.org, June 4-6;2009).

In the subsequent comments that followed from this posting, users conveyed the roadblocks placed before Egypt's civil society as well as the hypocrisy stemming from the American perspective. For example, one commenter posted, "Next week Mr. Obama will execute a 180 degree U-turn. He spoke today about Iraq being better off without a dictator, and yet Dear Mr. Hosni Mubarak has only been in power for about 28 years....Mr. Obama pretends to see both "sides"....To see him being "stern" with Israel is like watching a puppet master shouting at his own puppet" (www.sandmonkey, June 4th, 2009). Although blogs tend to produce indirect exchanges that basically become tied to a 
previous post, hardly producing any new or unique content, they do provide an outlet for expression. It is a simple, yet profound, need for a country in which self-expression is inhibited. Next, Baheyya (2009) takes a more academic approach to his blogs rather than the journalistic approach Abbas takes or the humanist approach SandMonkey takes.

Baheyya's view on President Obama's speech assumes an analytical method towards policy and foreign relations. Baheyya's post captures the political posturing of Abbas's view and the hypocrisy between elitist and political leaders of the SandMonkey's interpretation. However, taking it further Baheyya (2009) ties speech acts to the uprising of student activists in Iran and to the democratic futility in Egypt. In doing so, the hypocrisy and posturing in U.S.-Egypt relations are more profound.

"The Cairo speech of 4 June was a ceremonious peace offering thin on policy details and thick with effusive praise about Islam and Muslims. Fine, that's to be expected. Obama needs to inaugurate his term by distinguishing himself from George Bush's maniacal and destructive Middle East policies. So he came to Cairo to "reach out" to the Muslim world, "assalaamu alaykuming" [Muslim greeting for hello and good bye, meaning Peace be with you] and quoting from the Qur'an. This is why I didn't understand all the hoopla surrounding the speech, and all the socalled "analyses." There wasn't much there to analyze because it wasn't a policy speech, it was a big group hug.

Still, in light of Obama's forceful and precise words yesterday directed at Iran's rulers, at least a portion of whom are actually elected, I'm going to await some equally strong words directed at Egypt's ruler, who dares not put himself up for a real election. I'll be looking for the American President's condemnation of Egyptian police brutality and solidarity with citizens who "insist that their votes are counted and their voices heard." And when police block roads to polling stations and break up peaceful election rallies so that the opposition doesn't make gains, I'll be waiting to hear Obama's emphasis on "the universal right to free assembly and free speech." (http://baheyya.blogspot.com; June $25^{\text {th }} 2009$ blog).

What is unique about the revived activism in Egypt during this period is that banners and thematic claims were not the only driving force behind political discourse occurring on 
and off-line. Abbas could reach domestic ICT users as well connect to the international press, while SandMonkey and Baheyya could connect the socioeconomic gaps between activists with narratives that resonated between them. These multi-directional connections serve as testaments to the socializing power found in ICTs, particularly when considered with the transcendence of network logic and its multi-cultural connections.

By 2009, there were almost a million Facebook users, a figure that was increasing monthly. In fact, within a year that number increased to 3.4 million (Howard, 2010; p. 135; SpotOn, 2010; p. 8). Consequently, political conversations converged from diverse areas (domestic and international) and helped form multiple groups that not only selfgenerated into a vibrant community in which discourse and shared feelings helped shape and deepen bonds but also, affected cultural reflexivity. ICT socialization was impacting users and the user's environment.

Howard (2009) identified three roles in which ICTs helped support civil society. First, the ideational function exposes users to an array of ideas, content, images, and interests. In Egypt, expressive outlets existed in technology utilization and the actualized ideas produced were shared and implemented outside of it. "One survey reported that word of mouth from family and friends was used by $72 \%$ of Egyptians" to transmit information about political issues (Zhuo et al., 2011; p. 7).

Second, Howard (2009) identified the role of ICTs as a structural resource. In its traditional applications used by Kefaya and April 6th movement, ICTs facilitated collective behavior; however, during 2009, most activities were organized in virtual spaces. They were effective tactical sources in which materials were diffused, plans were 
coordinated or altered, and defiance transmitted across digital waves encouraging a likeminded order. For example, with another election less than two years away, a vibrant online community began campaigning for Mohammed ElBaradei, the former head of the International Atomic Agency and a person who had fallen out of favor with the Mubarak regime. Living in exile, ElBaradei maintained his political presence via ICTs. "It was in this context that a group of young Egyptians started a "fan" page on the social networking site Facebook dedicated to ElBaradei's potential candidacy. Before long this group had over 150,000 members" (Faris, 2010; p.1). Another example can be found when the April 6th movement linked with two distinct groups, one in Tunisa and the other, with Srdja Popovich of Otpor. Over the course of the next two years, leaders from all three groups collaboratively brainstormed via ICTs on broad political strategies, surveillance evasion, and practical issues like organizing blockades and defensive tactics against tear gas (Kirkpatrick and Sanger, 2011; p. 1-2).

The third and final role that Howard (2009) identifies is a figurative one. Through modernization and unique functions, ICTs symbolized the antithesis of a status-quo system predicated on economic exploitation and deprivation. They signified liberating spaces, social connections (abroad and domestic) and empowerment (Howard, 2009; p. 142). In a sense, ICTs came to symbolize Egypt's political culture in which socialization escaped the confines of an authoritarian regimen specifically designed to condition behavior. Accordingly, ICTs represented a collective technology intended to be used and shared among friends and families, for as Howard stated: "when civil society is online, citizens are given more possibilities for memberships in associations that neither the state 
nor social elites approve of" (Howard, 2009; p.153). Thus, while 2009 may have represented a regressive period for activism in Egypt, Obama's token speech reignited a virtual community and reconnected activism to the international media.

By the summer of 2010, Egypt would have over 3.4 million Facebook accounts, over $20 \%$ market penetration in Internet users, and over two-thirds penetration in mobile technology, including devices with broadband Internet capabilities (Freedom House, p. 201; SpotOn, 2010). Also, Twitter was growing in application and popularity with about $1 \%$ market penetration at the turn of 2010 (Zhuo et al., 2011; p. 1). In all, the summer of 2010 would witness the (re)convergence of these technologies and virtual communities, as they engaged the regime with overwhelming numbers and effectiveness.

\section{2: Police Brutality, Kahled Said, and Facebook Activism}

After Mahalla 2009, activism transformed into cyber-activism and in some ways projected a false sense of security for the regime. "The regime felt that it had eliminated organized resistance so thoroughly that it no longer needed to pay the traditional social bribes to guarantee political acquiescence" (Kandil, 2011; p. 17). However, one institution that never lost its swagger was the police force. Consistently brutal, the police were barbaric in their methods and exuded a ferocity that sometimes could not be contained. Every Egyptian household had at least one story to tell about an encounter with the police, and those that claimed they did not, probably, had sufficient cause not to recall the experience. The tales of police brutality even made its way into movies. One of the popular movies in 2008/2009 was titled 'Its Chaos.' 
The movie tells the story of a mid-ranking police officer seduced by power to such an extent that he unleashes a series of outrageous acts on innocent people. The irony of the movie is that the cruel acts were indicative of normal police behavior. The character was corrupt and took bribes; he found pleasure in torturing citizens, and at one point, even rapes his neighbor. However, the most telling part of the movie occurs when he yells "The Government is ME!!" at a crowd of protestors gathered outside the police station (Fahim, 2010; p.2). The movie ends with an angry mob swarming the police station as the police officer takes his own life. Within the first month, the movie grossed \$32 million U.S. dollars and its director came under scrutiny by the national press (ElMagd, 2008; www.military.com). However, being one of the prominent film makers in Egypt, the director issued a statement that he neither critiqued the regime nor endorsed it. "My movies are not calling for chaos, they are warning of it," (El-Magd, 2008; www.military.com). The director's statement was two years removed from the Egyptian revolution and only one year removed from one of the most infamous cases involving police brutality, the death of Khaled Said. His death inspired a revolution.

There are many reports about whom and what Khaled Said was. For example, many reports offer different perspectives on the man; some frame the man as a 28 year old business man, others depict him as a blogger and activist; while in some cases, he was characterized as a recreational drug user. The only absolute fact is that in June, 2010, Khaled Said was a victim of police brutality. The young man was dragged out of an Internet café by plain clothed police officers, and after exchanging words, he was beaten to death. According to witnesses, the beatings ended only after his head was repeatedly 
smashed on the concrete pavement as a final blow silenced Said's pleas for mercy (Fahim, 2010; p. 1-3). The police report would read that Said attempted to swallow drugs and as a result, died of asphyxiation. However, cell phone pictures of the corpse, leaked via ICTs, told a very different story. It was evident from the pictures that Said's jaw was broken, teeth smashed, and face battered and bloodied. The pictures ignited a firestorm of cyber-activism.

Unlike the rigidness of grass-roots campaigns in which all things are hinged on strategy, tactics, and methods, cyber-activism operates organically and without any formal structures. However, the two are "closely interrelated, since cyber-activism can help to foster and promote civic engagement, which, in turn, gives birth to various forms of mobilization" (Khamis and Vaughn, 2011; p. 5). After the picture of Khaled Said diffused via ICTs, a mid-level executive from Google (in Egypt) named Wael Ghonim headed a joint effort with Ahmed Salah from the April 6th movement, Washington based Nadine Wahab, and two others. Ghonim administered the site under the pseudonym "el shaheed" (the Martyr) and "filled the page with news about police abuse and torture" (Sutter, 2011; p. 2). Wahab would serve as back-up administrator in the U.S. just in case anything happened to Ghonim. Within one month, the site, titled "We are all Khaled Said", had over 100,000 followers and after few months, had a following of over 300,000 (Khamis and Vaughn, 2011; Giglio, 2011; p. 2). The site became the largest dissent group in Egypt and launched the image of Khaled Said as the new brand for protest.

Khaled Said appeared on t-shirts, web banners, flyers, graffiti tags, and posters. Politicians like Ayman Nour and Mohamed ElBaradei lent support with public 
proclamations against the police; ElBaradei even stopped by Said's home to offer his condolences (Al-Jazeera, June 26; 2010). "Silent stands," organized by the Facebook page's administrators called for people to come together to form human chains and stand silently as a sign of protest. These silent stands occurred periodically and were delegated through Facebook. They instructed the protesters to wear black and stand exactly four feet apart in order to circumvent the public association laws (see Figure 5.1). They even "launched a Twitter campaign using the hash tag \#KhaledSaid, exposing the new technology to a host of protesters" (www.movements.org).

Figure 5.1: The Silent Protest Honoring Khaled Said

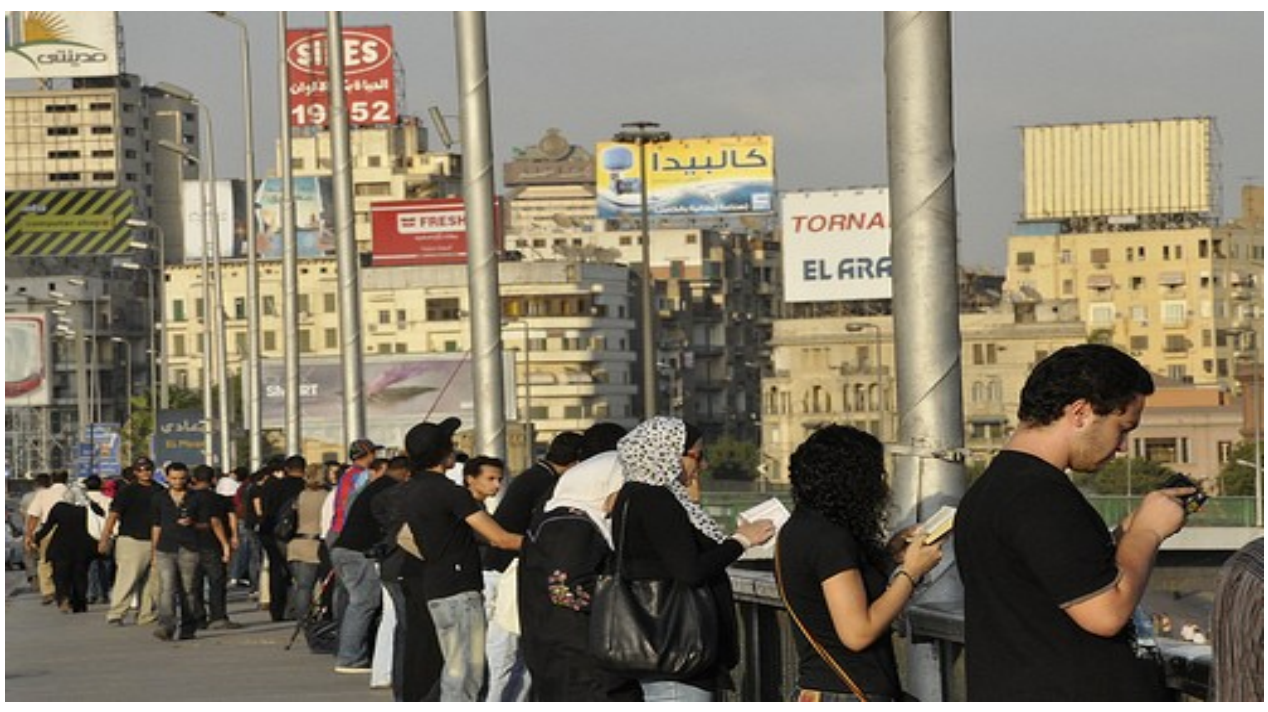

Source: www.movements.org- "Keeping an Eye on Police Brutality" accessed 6/12/2012

What is instrumental with the Khaled Said tragedy and the subsequent cyber phenomenon is that it resonated across the political divide. Khaled Said was anyone's son and was everyone's nightmare. At any time, any Egyptian could become Khaled Said. This was 
not about economics or mobilization or cultural distinction, it was about living in perpetual danger. In a sense, the politics of repression and the violence of tyranny created an intimate bond among Egyptians. Those with technology access facilitated the connection and socialized the public towards a new mode of defiance. As Verba (1995) argued, political participation is contingent on strong relationships. Khaled Said brought Egyptians together and through his death, close bonds transcended politics, but nonetheless, remained grounded by its realties. Passion-based bonds expanded political awareness and harnessed outrage and fear into a political movement relatively free of organization identity; that is, other than, "We are all Khaled Said". The Facebook page would play a vital role in the Egyptian revolution of 2011 as would the rising prices of wheat and the eruption in Tunisia.

\section{3: The Breaking Point}

The surge of protests that followed the summer of 2010 was met by rising wheat prices. By the fall of 2010, wheat had doubled in price and was hovering close to $\$ 300$ U.S. dollars, and was close to the same prices that triggered the labor movements of 2006 thru two thousand eight. Bush (2010) reminds us, "the protest in Mahalla was not the beginning of a workers' revolution but the way in which the demonstrations linked food prices to ongoing and sustained [struggles]" (Bush, 2010; p. 126). Stoking an already blazing social condition, labor unrests served to strengthen the sentiments that the status quo was at a breaking point. Before the regime could formulate any responsive 
strategies, police cruelty would once more trigger a civic eruption. Only this time, it was in neighboring Tunisia.

On December 17th, 2010, a little more than six months after the Khaled Said tragedy, a 26 year old food vendor from Tunisia was confronted by a policewoman conditioned to project power. It started when the policewomen approached Mohammed Bouazizi about selling vegetables without a license. Bouazizi attempted to pay the officer the equivalent of $\$ 7$ U.S. dollars, but the officer rejected. Upon seizing his cart and subsequently his livelihood, "the policewoman allegedly slapped the scrawny young man, spat in his face and insulted his dead father" (Abouzeid, 2011; p. 1-4). Humiliated and publicly shamed, the young man self-immolated in front of the Government building that issued licenses for street vendors just a few hours later. Over the course of three weeks and as Bouazizi struggled to live, Tunisians began to vent a collective anger on the social spaces provided by Information and Communication Technologies. "A cottage industry of bloggers and activists used the Internet to evade government censorship by creating alternative newscasts and building spaces online where individuals could publish information critical of the Government without attaching their names to it" (Howard et al., 2011; p. 7). Campaigns called for citizens, groups, and labor unions to mobilize a revolution. Professional syndicates were the firsts to answer the call and took to the streets (Howard et al., 2011; p. 8). On January 4, 2011, Mohammed Bouazizi died and the anguish that he felt at the end of his life resonated throughout the region. His death put an end to Ben Ali's twenty three years reign in Tunisia, and, subsequently, added to the invigorated spirit in Egypt. 
With over one million Twitter users, 3.4 million Facebook accounts, 20 million Internet users, and over 50 million cell phone owners, Egypt's information highway possessed a level of infrastructure and sophistication unparalleled in the Middle East (SpotOn, 2010; Freedom House, 2011; Zhuo et al., 2011). News about Tunisia erupted in Egypt, as did a fifty year old Egyptian who set himself on fire on January 17th in front of Parliament screaming against the police (Gigi Ibrahim-Gsquare 86-Tweet, January 17, 2011). The Facebook organizers of "We are all Khaled Said" created a Facebook events page titled "The Day of the Revolution Against Torture, Poverty, Corruption, and Unemployment" and invited the country to join them on January 25, 2011. More than 80,000 people confirmed participation as the event diffused via Twitter feeds, blog networks, emails, and text messages (Sutter, 2011; p. 1). Activists and angry citizens from across 12 provinces clicked yes to the event, thereby, elevating a day of protest into a national movement. It was the apex at which subjective and rational will found synergy and passion aspired to sacrifice. Information and Communication Technologies became the vessel for expression, strategy, and mobilization. Ahmed Salah commented on the days preceding the event: "Facebook, Twitter, and emails created a 'parallel Egypt' on the Internet" (Sutter, 2011; p. 3). The regime had lost its control over associations and information.

On January 24, 2011, activists remained diligent. Below are some of the Tweets and postings from the virtual world on the night before the event:

Wael Ghonim tweeted: "Despite the warnings I got from my relatives and friends, I'll be there on \#Jan25 protests. Anyone going to be in Gam'et Dewal protest? 
TravellerW tweeted (anonyomous): "Yes, I'm worried about tomorrow. Which is exactly why I'm going - we can not and will not let them scare us. \#Jan 25.

SandMonkey tweeted: "For when and where the revolution will be and other important info. Go here: http://bit.ly/Jan.25egypt (Tweets from Jan. $24^{\text {th }}$; Idle and Nunnis ed., 2011; p. 25).

In addition, bloggers and organizers sent out information packets instructing participants on how to demonstrate. Thus, the Egyptian revolution existed, at least in its initial phases, as a cyber-movement that not only mobilized the public, but, also, educated participants on how to protest. Some of the materials distributed during these days were sent out via emails and flyers (see Figure 5.2). 
Figure 5.2: Engagement Tactics Spread Via Emails and Flyers

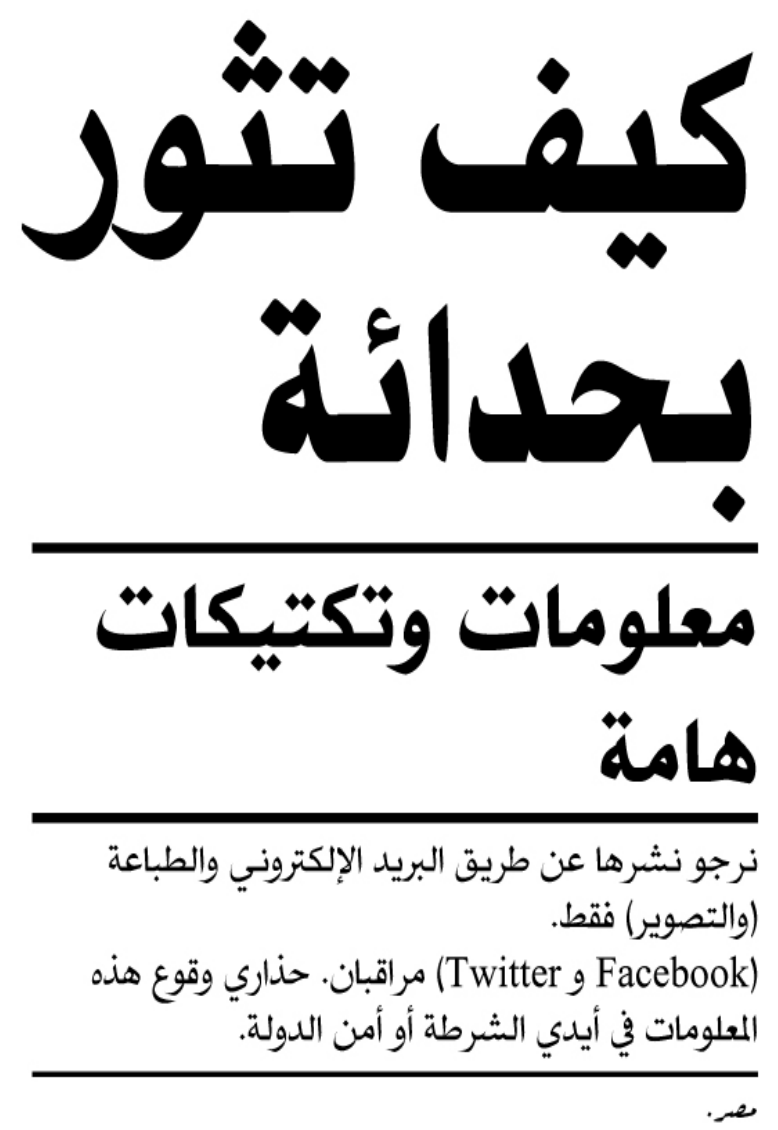

\section{How to Protest Intelligently}

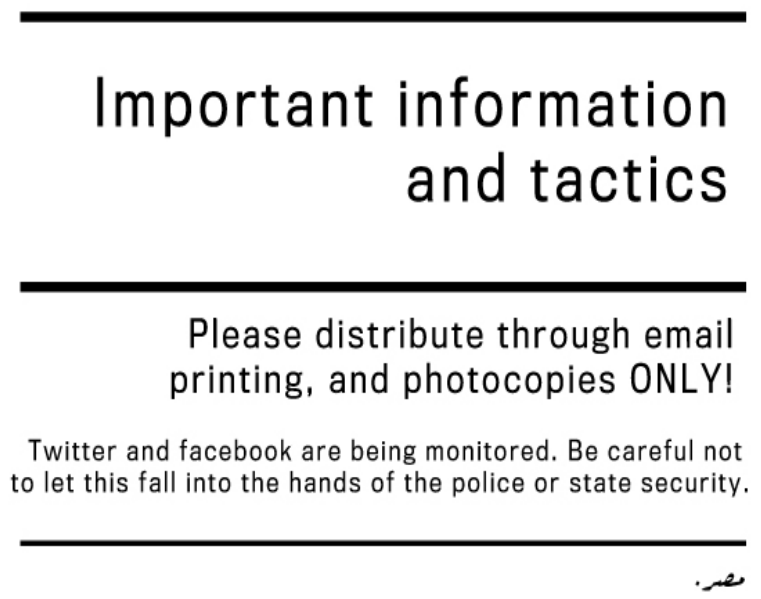




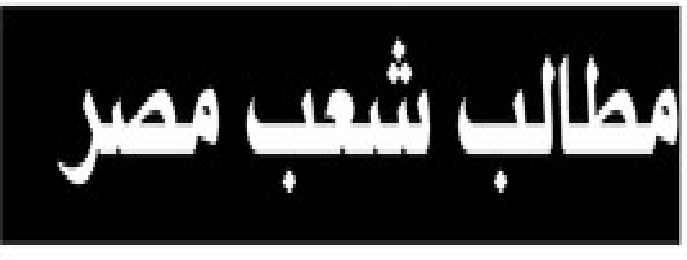

| - إبقاط حكم مبارك ووزرائه.

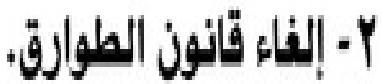

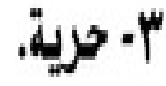

؛ ؛ عدالة.

0 - تكويز كوهة جليدة غير عبكرية

يكوز قالبها على الشب المصري.

1 ا الإدارة السلية لجهيع المواردة المصرية.

\section{The Demands of the Egyptian People}

1. Tho downfall of the regime of Hosnl Mubarak and his ministers.

2. The cessation of the Emergency Law

3. Froodom

4. Justice

5. The formation of a now, non-milltary govornment with the interests of the Egyptian people at heart.

6. The construetlve administratlon of all of Egypt's resources. 


\section{خطوات التنفيد}

I- التجهير مع الأصدقاء والجيران في الشوارع

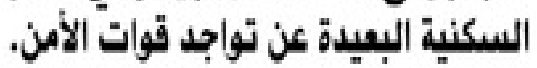
Y - الهتاف بإسم مصر وحرية الشب (هتافية

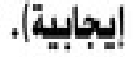

ץ- تشجيع سكان العمارات للإنضهام (بشكل إيجابي).

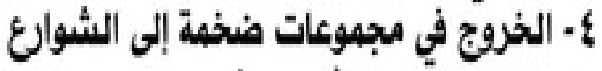
الرئيسية لجمع أكبر حشد مهكن.

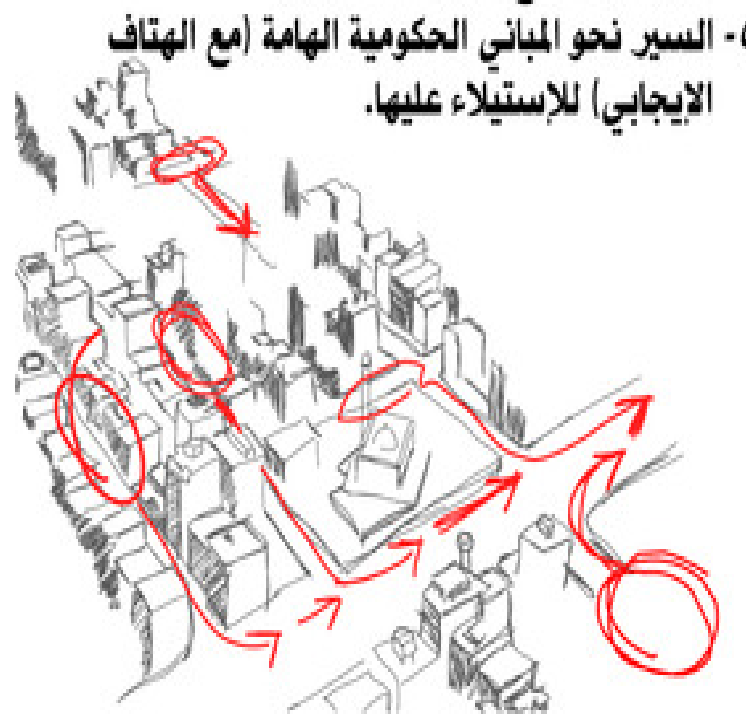

\section{Steps for Garrying} Out the Plan

1. Assemble with your friends and neighbors in residential streets far away from where the security forces are.

2. Shout slogans in the name of Egypt and the people's freedom (positive slogans).

3. Encourage other residents to join in (again with positive language)

4. Go out into the major streets in very large groups in order to form the biggest possible assembly





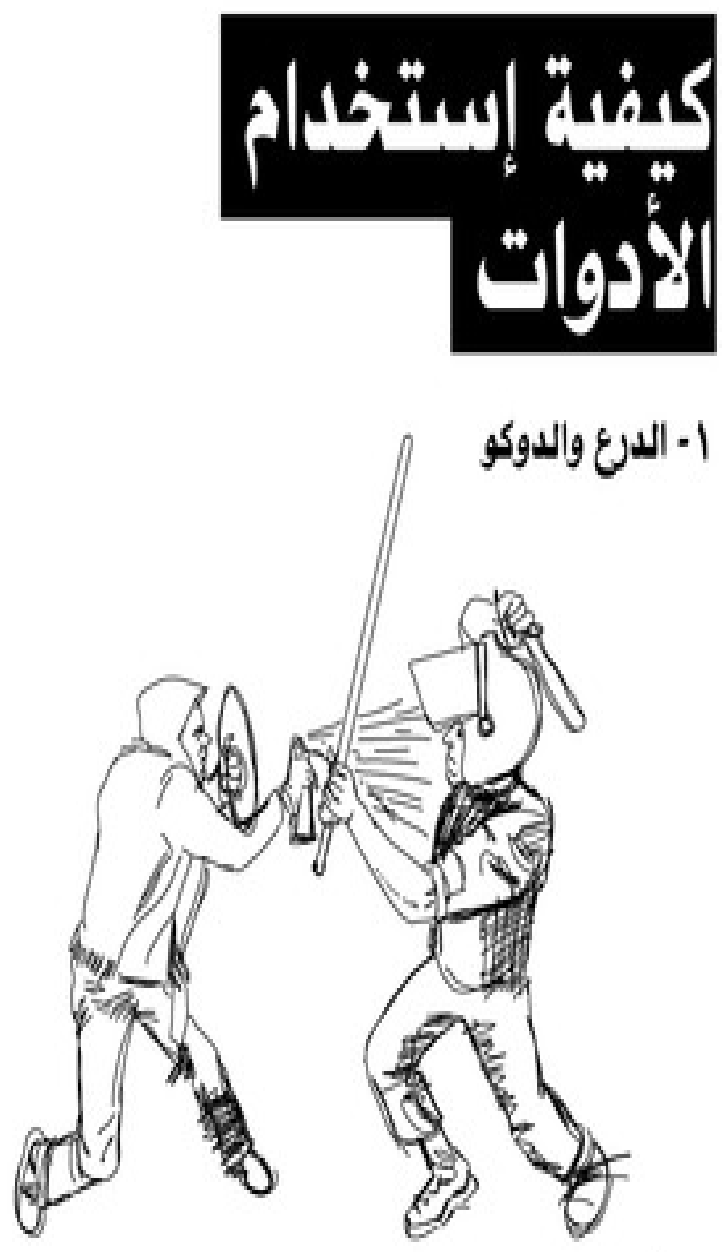

إثبت مكانك يامصري. صد العصاية بالدرغ وأنت تقوم بالرش في الوجانه.

\section{How to Use the}

Acoessories



HOLD YOUR GROUND, EGYPTIANI

Block the truncheon with your shield as you'ro spraying thom in the faco. 


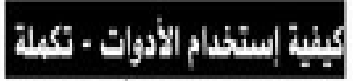

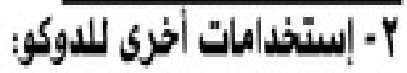

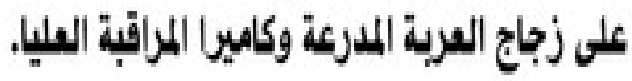

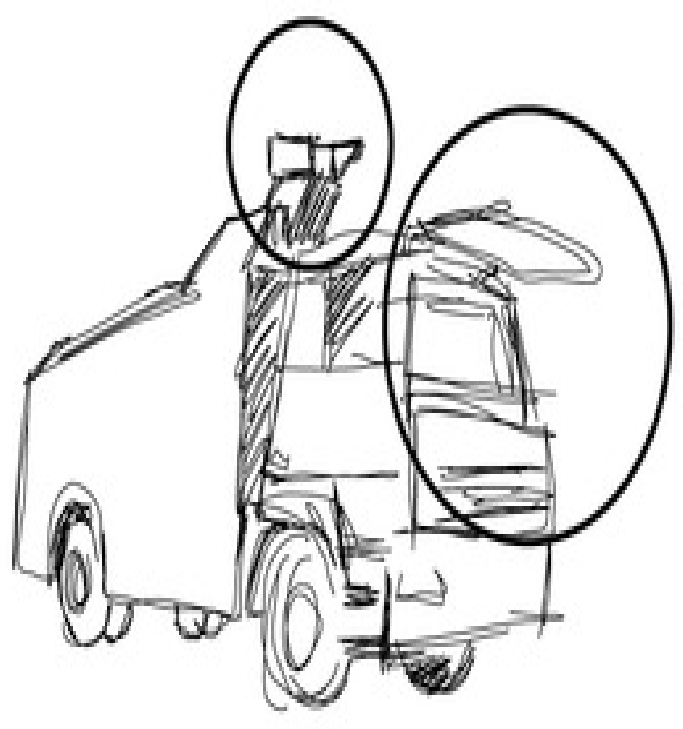

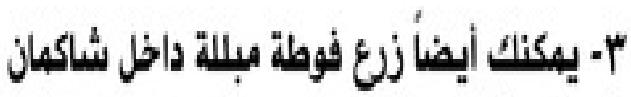

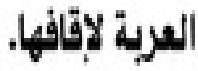

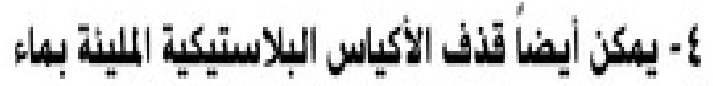

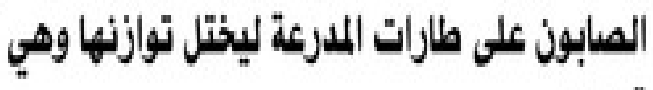

How to Uno the Ascunarilus

2. Other uses for Spray paint: on the windshiolds of armored trueks and on mounted survolllanoo almeras

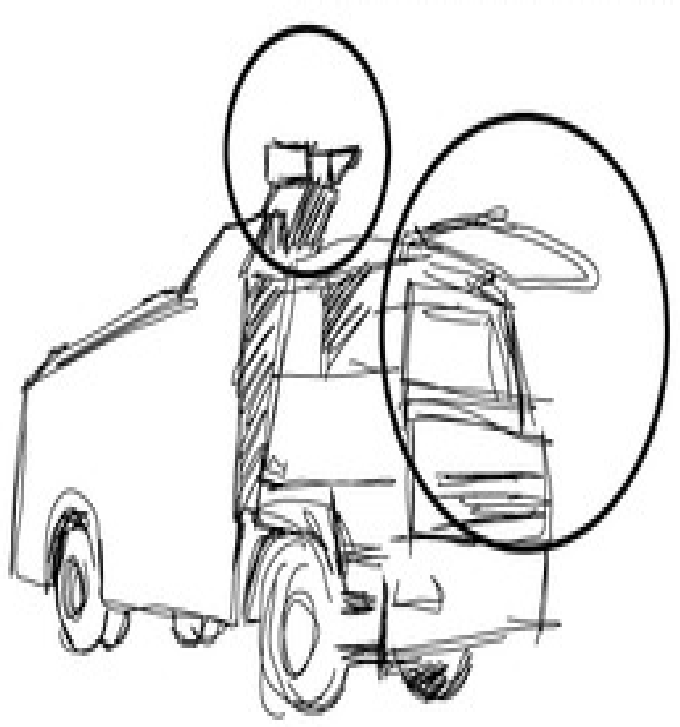

3. You can aloo stick a wot towal in the whicle's axhaust to stop it

4. You can also throw plastic bage fillad with liquid soap under the whouls of the armered trueks to discupt thoir balance as thay're moving. 

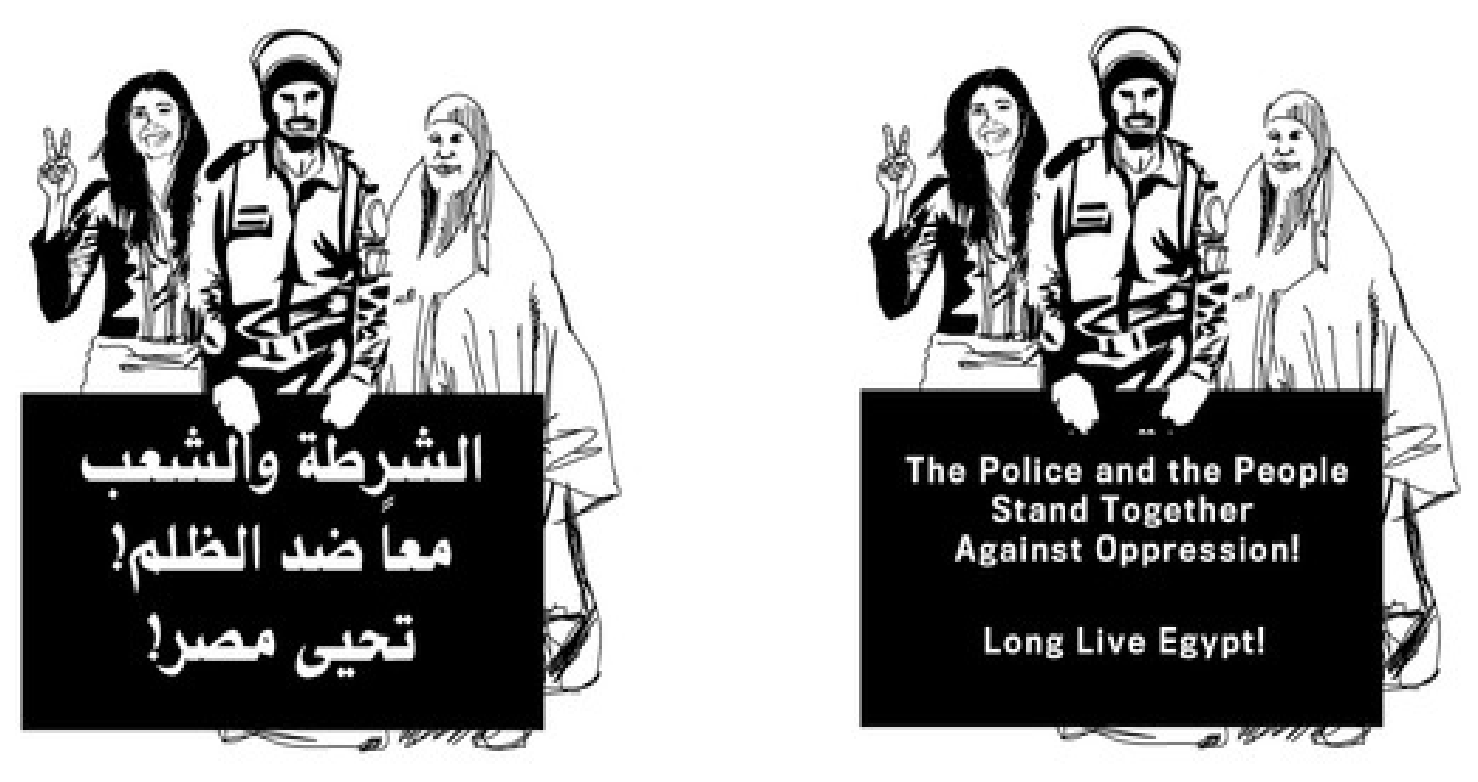




$$
\text { ا - نرجو عدم إستخدام ال (facebook) }
$$

r إنشر عن طريق ال email أو الطباعة والتصوير،

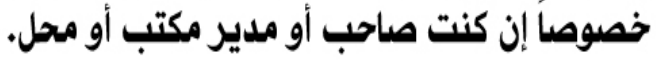

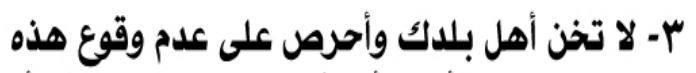

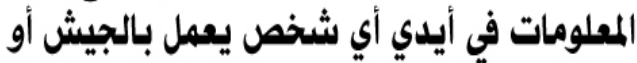

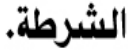

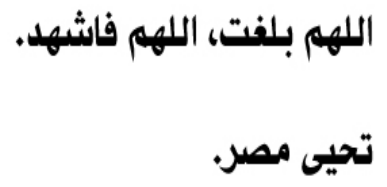

\section{How to Publish and Disseminate}

\section{This Information}

1. We ask you not to use Twitter or Facebook or other websites because they are all monitored by the Ministry of the Interior.

2. Distribute by email or printing or photocopying especially if you own an office or store.

3. Do not betray your fellow citizens and ensure that this not fall into the hands of anyone who works for the police.

Now that you know, please pass it on! Long live Egypt!

Source: Madrigal, January 27, 2011: Reprinted with permission from The Atlantic Journal. URL: http://www.theatlantic.com/international/archive/2011/01/egyptian-activists-action-plan-translated

As evident from the last page of advice, organizers anticipated a regime crackdown on the Internet, a lesson learnt from Mahalla 2009, and urged information be passed by word of mouth and hand to hand exchanges. Accordingly, on January 25, 2011, after years of organizing, planning, discussing, and experiencing, the Egyptian revolution broke out. Demonstrations in Alexandria, the Nile Delta, Mansura, Tanta, Aswan, Assiut, and the Suez joined in anti-government demonstrations. "The collective 
perception that a revolution was happening [in places] where it was least expected gave everyone the confidence necessary to realize that it could happen everywhere" (Bameyh, 2011; p. 2). Over the course of eighteen days, a non-violent protest linked across the socioeconomic divide overthrew a despotic regime of almost three decades. Without an identity to the movement, millions of people crystalized around the notion of change and the reality of tyranny, and mobilized via information and communication technology.

However, what is evident from the days leading up to the revolution was that activism had evolved. That is, the consciousness of the people had changed. Information and Communication Technologies enabled the expression of this consciousness to resonate throughout the virtual realms prior to the days leading up to January twenty fifth. Some of the Tweets and Facebook postings shared among the activists expressed this change. For example, the evolved digital historians tweeted: “Today's our day as Citizen Journalists to cover and share the truth freely. Regardless of the outcome we are winners because we are a team" (Idle and Nunnis ed., 2011; p.34). Likewise, Gigi Ibrahim expressed an empowerment by recognizing that the mystique of the Police was not as psychologically crippling as once conceived. She posts, "Don't let the police intimidate us with their presence, they have always been there and always will, it's time to move" (Idle and Nunnis ed., 2011; p.34). Indeed, the extent of change had evolved from probing and opening spaces to tearing down barriers and constructing change. In Egypt, Information and Communication Technologies enabled the transformation to occur by consolidating rational and subjective wills to remove an entrenched President. 


\section{CHAPTER 6}

\section{RESULTS AND CONCLUSION}

In conclusion, the cases presented in this study lend credence to the hypothetical claim that in Egypt, ICT socialization enabled a political self-awareness to occur in each cycle of change from the Kefaya movement to the April 6th movement to the 2011 Revolution and evolved political activism into a social force capable of organic mobilization. Evolving from a tactical resource that enabled digital historians to counter the regime's framing of news and events to a sphere in which a virtual community created unique content, ICTs (re)socialized segments of society and chartered a course for activism. The unique features linking the activists' transformations from the Kefaya movement to the April 6th movement can be traced to technologies' expansion into social networks. Facebook and Twitter, although still in its infancy stages in 2008 and 2009, helped expand virtual engagement by opening up channels for communication.

In this new form, discourse represented an organic interaction among individuals in which content remained undefined and unique. In other words, whereas blogs were posted with one distinct perspective, i.e., of the writer's, Facebook and Twitter functioned more communally and inclusively. Subsequently, activism responded to social networking sites in 2008 generating a nation-wide labor movement that hinged labor grievances to broader political issues. Yet, the social networking applications required an issue centric ideal that inspired risk-taking performance. Technology could influence the environment, as in 2008 , but social networks were still dependent on bonds formed outside the realms of ICTs. This plays into the strengths of a system designed to 
prevent collective action which in turn limits the commitment between activists, since relationships are inhibited from forming the intimate bonds necessary for risk taking performances.

The year 2009 serves as an example in which regime crackdowns, increased surveillance methods, and a lack of clear issue-centric attractors regressed activism in Egypt. Certainly, affinity ties between labor and activist groups like April 6th remained weak and easily obstructed since the whole relation remained contingent on labors' demands. Once labor grievances were reconciled by Government concessions, affiliations were no longer harmonious in their cause. Yet, the inabilities stemming from the 2009 call to strike were not entirely contingent on the organizers' miscalculations of labor's alliances.

Specifically, bonds across the political divide that formed via ICTs did not possess a sufficient amount of time for individuals to reconcile personal needs with the collective pull desired by organizers. Accordingly, Mahalla in 2009, while possessing over 70,000 Facebook followers, could not satisfy individual issues. In short, the movement was lost because a lack of empathy affected the unity and the harmony required for mass mobilization as well as the willingness to engage in risk-taking performances. What was missing from the April 6th movement's cause were passions and technological reflexivity.

A main point of divergence among the eras of activism marked as the Kefaya movement, the April 6th movement, and the 2011 Revolution is the manner in which social networks evolved ICT socialization. By 2011, a level of sophistication existed 
among users of technology. Communication and social networks transcended boundaries and established a community of like-minded members that enhanced political awareness and strengthened the spirit of defiance. Egyptian activists, Tunisian activists, and East European activists collaborated with one another, thereby, expanding knowledge vital for engagement within one's country. More importantly, Facebook and Twitter increased the speed of information diffusion as well as the rate of ICT socialization. This is a consequence of a reflexive evolution between technology and activism in which the interdependence reached a level that was sufficient for organic mobilization to occur. Figure 6.1 illustrates. As a result, exponential growth occurred without limits.

Figure 6.1: Info. Diffusion and Socialization Model

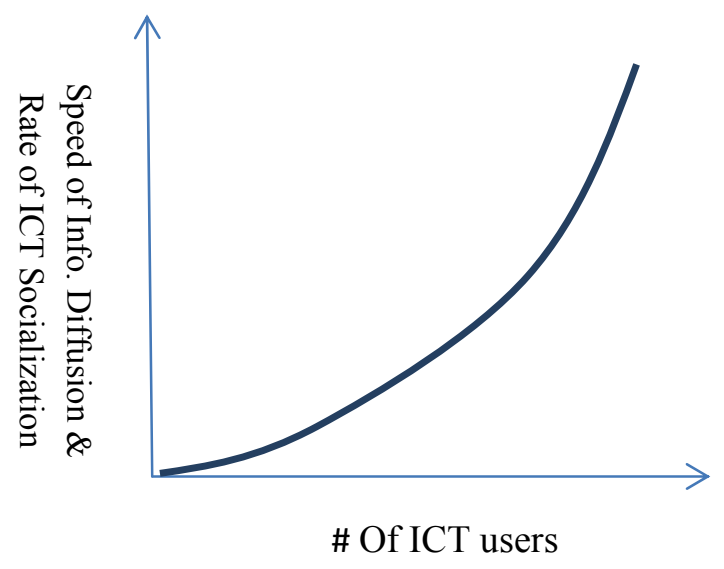

That is why individual actors like Wael Ghonim could crystalize political engagement through subjective will, and why a web page like "We are all Khaled Said" could become the largest dissent group of the day. ICTs, and specifically the increase in socialization, conditioned a technological reflexivity, while its products such as the 
'Silent Protests' produced a cultural reflexivity that diluted the regime's control over behavior. What is also unique about the events in 2010 is that the surge of activism was not tied to a specific demand or group. A passion for change was no longer an exploration into things considered taboo while virtual spaces, although still a point of contestation represented a modern day underground.

When comparing the data for technology diffusion between 2004-2009 and 2010, the volume of ICT usage is profound. While Facebook and Twitter were in their infancy stages around the Mahalla Strike of 2008 and 2009 with less than two thousand twitter accounts in 2009 and approximately one million Facebook accounts in that same year, it is clear that social networks were still lagging behind the traditional forms of online communications (email, blogs, and websites). However, by 2010, there were almost 3.4 million Facebook accounts and over one million Twitter accounts. Thus, while an increase in the level of users increased the potential for reflexivity to have an impact on political socialization and mobilization, the data does not fully support that an increase in social network users was the underlying difference.

In 2008, Facebook was at its infancy stage in Egypt and was able to mobilize about 60,000 participants to boycott a day of work. In 2011, Facebook users had almost tripled, yet the January $25^{\text {th }}$ Day of Rage mobilized roughly the same number as 2008 . However, a difference can be found in the spirit of defiance. For the most part, in 2008, 60,000 protesters took a day off and risked very little when compared to the 2011 protestors. The 2011 protest was a direct threat to the regime since it correlated with Ben Ali's fall, Khaled Said's death, and economic grievances. The physical act of protest was 
in itself a life risking endeavor since the regime's response was unpredictable. However, the spirit of revolution in 2011 was at its most passionate. In this regard, ICTs served the passions of many by transforming an idea into reality.

With passions at its most intense, the initial wave of protests that sprouted in different regions represented the vanguard of engagement. Those on the frontline utilized ICT to report, document, and inspire users on the sidelines. Consequently, an exponential growth in participation occurred as minute by minute accounts sent out via texts, tweets, Facebook, and YouTube diffused instantly. This could not have happened in 2005, 2008, or 2009 since social networks were still developing. Evolved social networks connected via ICTs changed the speed of socialization as well as the speed of information diffusion. This fact not only explains the meteoric rise of "We are All Khaled Said" but also, supports the hypothetical claim that an increase in ICT socialization, unlike 2005 and 2008, evolved political activism and enabled organic mobilization. Figure 6.2 summarizes the findings. 
Figure 6.2: Results Summary

\begin{tabular}{|c|c|c|c|}
\hline & $\begin{array}{l}\text { KEFAYA (2004- } \\
\text { 2007) }\end{array}$ & APRIL (2008-2009) & 2011 \\
\hline $\begin{array}{l}\text { Degree of } \\
\text { Participation }\end{array}$ & $\begin{array}{l}\text { Hundreds to Ten } \\
\text { Thousand }\end{array}$ & Up to 60,000 & $\begin{array}{l}60,000-\text { National } \\
\text { mobilization }\end{array}$ \\
\hline ICT Penetration & $\begin{array}{ll}\text { Cell- } & \mathbf{1 0 - 4 0 \%} \\
\text { Internet- } & 6-15 \% \\
\end{array}$ & $\begin{array}{lr}\text { Cell- } & \mathbf{5 0 - 7 0 \%} \\
\text { Internet- } & \mathbf{2 0 \%} \\
\text { Facebook- } & \mathbf{1 \%} \\
\text { Twitter-NS } & \\
\end{array}$ & $\begin{array}{lr}\text { Cell- } & \mathbf{8 0} \%> \\
\text { Internet- } & \mathbf{2 3 \%}> \\
\text { Facebook- } & \mathbf{4} \% \\
\text { Twitter- } & \mathbf{1 \%} \\
\end{array}$ \\
\hline Themes & $\begin{array}{l}\text { Regime Legitimacy, } \\
\text { Corruption, Foreign } \\
\text { Policy, and } \\
\text { Economy } \\
\text { (RATIONAL WILL) }\end{array}$ & $\begin{array}{l}\text { Regime Legitimacy, } \\
\text { Corruption, Foreign } \\
\text { Policy, Economy, } \\
\text { and Labor (Rational } \\
\text { WILL) }\end{array}$ & $\begin{array}{l}\text { Revolution, } \\
\text { Regime Brutality, } \\
\text { and, Rage } \\
\text { (Subjective.WILL) }\end{array}$ \\
\hline Effectiveness & $\begin{array}{l}\text { Broke Taboos, } \\
\text { Archived, Expanded } \\
\text { Social Realms, and } \\
\text { Branded Change }\end{array}$ & $\begin{array}{l}\text { Integrated Labor, } \\
\text { Scope of Campaign, } \\
\text { Inspired Waves of } \\
\text { Strikes }\end{array}$ & Toppled Regime \\
\hline ICT Utilization & $\begin{array}{l}\text { Emails, Texts, } \\
\text { YouTube, Blogs, } \\
\text { Flyers, Websites, } \\
\text { and Newspaper }\end{array}$ & $\begin{array}{l}\text { Facebook, Texts, } \\
\text { Emails, Tweets, } \\
\text { Blogs, and Flyers } \\
\text { (limited) }\end{array}$ & $\begin{array}{l}\text { Facebook (HUB), } \\
\text { Emails, Texts, } \\
\text { Tweets, Blogs, } \\
\text { YouTube, Flyers... }\end{array}$ \\
\hline Limitations & $\begin{array}{l}\text { Confined to Urban } \\
\text { Center }\end{array}$ & $\begin{array}{l}\text { Bonds definitive and } \\
\text { apathetic }\end{array}$ & Achieved Goal \\
\hline
\end{tabular}

$* *$ Red represents an evolved condition 


\section{1: Recommendations for Further Research}

The purpose of this study was to gauge the impact of Information and Communication Technologies on state-society dynamics. Accordingly, with the resurgence of social movements in the new millennium and with the rise of the Arab Spring in 2011, activism in Egypt represented a robust data set in which the integration of ICTs corresponded with the rise of defiant activities in the country. The study focused on the role of ICTs throughout three specific periods: The Kefaya movement, the April $6^{\text {th }}$ movement, and the 2011 revolution. The findings support the claim that ICT socialization enabled a mass mobilization to occur at levels sufficient to sustain a revolution. In addition, the networks formed via ICTs played an instrumental role in formulating strategic initiatives which could be transplanted from one location to the next. Therefore, any future research on this subject should include the Arab Spring in its totality. That is, a more comprehensive analysis on Tunisia, Libya, and Syria may provide greater insight on the dynamics between state and society and specifically, the contending spaces that make up civil society.

Furthermore, throughout the case study on Egypt, women played a vital role in activism. Whether blogging, administering Facebook events, or utilizing Twitter to transmit information, women contributed heavily to the Revolution's success. However, there is a glaring shortage in the literature about gender roles. The role of women during the Egyptian revolution, and for that matter the Arab Spring, would provide an interesting perspective on gender relations in the Middle East. For example, were gender prejudices 
prevalent within activist movements? And if so, how did ICTs mask or augment these issues?

Another interesting dynamic that requires further attention lies in networks. If networks are able to dilute the sense of nationalism and transcend boundaries, do branded movements create a global community that forces governments to consolidate authority? In essence, will we have a Federation of States monitoring the Internet and all the transactions that occur online?

Similarly, Kefaya and Otpor not only branded movements but also co-opted grievances. This has been a growing trend in cyber-activism. In fact, with the growing reputation of Anonymous - a cyberactivist community that operates without organizational structures - participants with high ICT proficiency have banded together with their own set of principles and moralities. The implications of such outcomes can affect the economic, military, and security spheres of a country and by extension the global community. Accordingly, will conflicts evolve into digital battlefields? Investigation on these questions may help identify trending patterns in international relations, economics, and sociology. While these questions may help serve future understanding, one thing is certain today. A war over information is being waged right now via ICTs and it entails users from across the globe converging on governments and corporations. The way Governments respond will undoubtedly affect our understanding on freedom. 


\section{BIBLIOGRAPHY}

Abass, Wael. http://misrdigital.blogspirit.com/archive, (2005-2011).

Abouzeid, Rania. "Bouazizi: The Man Who Set Himself and Tunisia on Fire." Time Magazine World, Janurary, 21, 2011. Accessed on 6/13/2011. http://www.time.com/time/magazine/article/0,9171,2044723,00.html

Acemoglu, Daron \& James A. Robinson. Economic Origins of Dictatorship and Democracy. New York: Cambridge University Press. 2006.

Apps, Peter. "Serbian activist teaches lessons in revolution." Reuters. June 16, 2011. Accessed on 6/1/2012. http://af.reuters.com: p. 1-3.

Austin, J.L. How To Do Things With Words, $2^{\text {nd }}$ ed.. Cambridge: Harvard University Press. 1962

Baheyya. http://baheyya.blogspot.com/Archives, (2005-2011).

Bamyeh, Mohammed A. "The Egyptian Revolution: First Impressions from the Field." Sociology of Islam \& Muslim Societies. Portland State College of Liberal Arts and Sciences, February 11, 2011.Accessed on 10/08/2012. www.pdx.edu/sociologyof islam.

Beinin, Joel. "Workers' struggles under socialism and neoliberalism.” Egypt the Moment Of Change. Ed. By Rabab El-Mahdi and Phillip Marfleet: Zed Books. 2009.

Boswell, Allan."How Sudan used the Internet to crush protest movement". McClatchy Newspapers (April 6th, 2011). Accessed on 2/15/2012. http://www.mcclatchydc. com/2011/04/06111637/sudans-government-crushed-protests.

Braxton, Jesse. "Life Finally Must Win: The Otpor Movement and the Fall of Milosevic." Nonresistance.org. May 25, 2006. Accessed on 7/9/2012.

Brundidge, Jennifer \& Ronald E. Rice. "Political engagement online: Do the information rich get richer and the like-minded more similar." The Routledge Handbook of Internet Politics. Ed. By Andrew Chadwick and Phillip N. Howard: Routledge, 2010.

Bush, Ray. "The land and the people." Egypt the Moment of Change. Ed. By Rabab ElMahdi and Phillip Marfleet: Zed Books. 2009.

Bush, Ray. "Food Riots: Poverty, Power and Protest." Journal of Agrarian Change, Vol. 10 No. 1, January 2010: p. 119-129 
Della Porta, Donna \& Sidney Tarrow. "Transnational Processes and Social Activism: An Introduction.” Transnational Protests \& Global Activism. Ed. By Donna Della Porta and Sidney Tarrow: Rowman \& Littlefield Publishers. 2005.

Effing, Robin, Jos van Hillegersberg and Theo Huibers. "Social Media and Political Participation: Are Facebook, Twitter, and YouTube Democratizing Our Political System”. Electronic Participation. Tambouris, Macintosh, and Bruijn Ed. Netherlands Springer Publishing. 2011.

Eickelman, Dale. "New Media in the Arab Middle East and the Emergence of Open Societies, in Robert Hefner Ed., Remaking Muslim Politics. Princeton University Press, 2005. 37-59.

Eid, Gamal, ed. "Implacable Adversaries: Arab Governments and the Internet." The Arabic Network for Human Rights Information, 13 December 2006: 136.

"ElBaradei leads anti-torture rally." Al-Jazeera English, June 26, 2010. Accessed on 06/12/2012. www.aljazeera.com/news/middleeast/201/06/20106264295520: p.1-7.

El-Hennawy, Noha and Hassan M. Fattah. "Violence Mars Egyptian Referendum About Presidential Vote." The New York Times, May 26,2005. Accessed on 09/28/2011. www.nytimes.com/2005/05/26/international/26egypt.html

El-Mahdi, Rabab. "The democracy movement: cycles of protest." Egypt the Moment of Change. Ed. By Rabab El-Mahdi and Phillip Marfleet: Zed Books. 2009

El-Naggar, Ahmad El-Sayed. "Economic policy: from state control to decay and corruption." Egypt the Moment of Change. Ed. By Rabab ElMahdi and Phillip Marfleet: Zed Books. 2009

Entman, Robert M. Projections of Power: Framing New, Public Opinion, and U.S. Foreign Policy. Chicago: The University of Chicago Press. 2004.

Erdbrink, Thomas. "Web Controls Sink Iran Deeper into Isolation". Miami Herald No. 150 Final Edition, 2012, p. 22A.

Etling, Bruce, John Kelly, Robert Faris, and John Palfrey. "Mapping the Arabic Blogosphere: Politics, Culture, and Dissent." Berkman Center of Research at Harvard University, Publication No. 2009-09. June, 2009: p.1-50.

Fahim, Kareem. "Death in Police Encounter Stirs Calls for Change in Egypt." The New York Times. July 18, 2010. Accessed 09/28/2011. www.nytimes.com/2010/07/19/world/middleeast/19abuse.html: p.1-4. 
Fahmi, Wael S., "Bloggers' street movement and the right to the city. (Re)claiming Cairo's real and virtual 'spaces of freedom."' Sage Publications, 3/28/2009. Accessed on 4/30/2011. http://eau.sagepub.com/content/21/1/89:p. 89-107.

Faris, David. "Revolutions without Revolutionaries? Social Media Networks and Regime Responses in Egypt." University of Pennsylvania Dissertations. 2011

"Freedom on the Net 2011: Egypt." Freedom House, January, 201: p.1-8.

Gilio, Mike. "“We Are All Khaled Said': Will the Revolution Come to Egypt?" The Daily Beast, January 22, 2011. Accessed on 06/12/2012. www.thedailybeat.com/articles/2011/01/22: p. 1-3.

Goldsmith, Jack and Tim Wu. Who Controls the Internet?. New York: Oxford University Press.2006.

Gurr, Ted R. and Jack A Goldstone. "Comparisons and Policy Implicatons". Revolutions of the Late Twentieth Century. Jack A. Goldstone, Ted Robert Gurr, and Farrokh Moshiri Ed.,Wesview Press. 1991.

Habermas, J. The Structural Transformation of the Public Sphere: An Inquiry into a Category of Bourgeois Society. Cambridge, MA: MIT Press, 1989.

Hamzawy, Amr. "Egypt: Regression in the Muslim Brotherhood's Party Platform?" Arab Reform Bulletin. October 2007.

Hegel, G.W.F. Introduction to The Philosophy of History. Cambridge: Hackett Publishing Company. 1988.

Hoppock, Julia. “Obama's 'Change Slogan' Gets a Change.” $A B C$ News, September 13, 2008. Accessed on 06/11/2009. http://abcnews.go.com/blogs/politics/2008/09: p.1-3.

Howard, Phillip N. "Book Review of The Net Delusion: The Dark Side of Internet Freedom." Perspectives on Politics, December 2011, Vol. 9, No.4: p.895-897.

Howard, Phillip N. "Reply to Evegny Morozov's review of The Digital Origins of Dictatorship and Democracy: Information Technology and Political Islam”. Perspectives on Politics, December 2011, Vol. 9, No.4: p.900.

Howard, Phillip N. The Digital Origins of Dictatorship and Democracy: Information Technology And Political Islam. New York: Oxford University Press. 2010.

Howard, Phillip N, Aiden Duffy, Deen Freelon, Muzammil Hussain, Will Mari, Marwa Mazaid. "Opening Closed Regimes: What Was the Role of Social Media During 
the Arab Spring?" Project on Information Technolgoy and Political Islam. January, 2011. Working Paper: p.1-30.

IMF. "Primary Commodity Prices". http:// www.imf.org/external/ $\mathrm{np} / \mathrm{res} / \mathrm{commod} /$ index.asp. Accessed 3/11/2012.

Isherwood, Tom. "A new direction or more of the same? Political blogging in Egypt." Arab Media and Society, September, 2008: p.1-16.

Kalathil, Shanthi, and Taylor C. Boas. Open Networks, Closed Regimes: The Impact of the Internet on Authoritarian Rule. Washington, DC: Carnegie Endowment For International Peace, 2003.

Khalil, Majdi, "Between the Kefaya and Free Officers Movements." Elaph.com, December 13, 2005.

Khamis, Sahar and Katherine Vaughn. "Cyberactivism in the Egyptian Revolution: How Civic Engagement and Citizen Journalism Tilted the Balance." Arab Media Society. Issue 13, Summer, 2011: p. 1-30.

Kandil, Hazem. "Revolt in Egypt.” New Left Review, No.68. March/April,2011: p.1755.

Kirkpatrick, David D. and David E. Sanger. "A Tunisian-Egyptian Link That Shook Arab History.” The New York Times, February 13, 2011. Acessed on 09/30/2011. www.nytimes.com/2011/02/14/world/middleeast/14egypt-tunisia-protests.html: p. 1-4.

Lynch, Marc. "Beyond the Arab Street: Iraq and The Arab Public Sphere", Politics and Society, Vol.31 No. 1, March 2003: p.55-91.

Lynch, Marc. Voices of the New Arab Public: Iraq, Al-Jazeera and Middle East Politics Today. New York, NY: Columbia University Press, 2006.

Lynch, Marc. "Young Brothers in Cyberspace." Middle East Report 245, Winter 2007). http://www.merip.org/mer/mer245/mer245.html.

Madrigal, Alexis. "Egyptian Activists' Action Plan: Translated."The Atlantic, January 27, 2011. Accessed on 1/29/2012. http://www.theatlantic.com/ international/ archive/2011/01/egyptian-activists-action-plan-translated/70388: p. 1-10.

Massoud, Tarek. "The Upheaval in Egytp and Tunisia: The Road to (And From) Liberation Square." Journal of Democracy Vol. 22, No. 3. July, 2011: p.1-34.

McClure, Bud A. Putting a New Spin on Groups: The Science of Chaos. Taylor and 
Francis Group. London: 2005.

Mehanna, Omnia. "Internet and the Egyptian Public Sphere." Africa Development, Vol. XXXV, No. 4, 2010, pp. 195-209.

Morozov, Evegeny. "Response to Phillip N. Howard's review of The Net Delusion: The Dark Side of Internet Freedom”. Perspectives on Politics, December 2011, Vol. 9, No.4: p.897.

Morozov, Evegeny. "Book Review of The Digital Origins of Dictatorship: Information Information Technology and Political Islam”. Perspectives on Politics, December, 2011Vol.9, No.4: p.897-900.

Morozov, Evegeny. The Net Delusion: The Dark Side of Internet Freedom. New York; Public Affairs, 2011.

Morrow, Adam and Khaled Moussa al-Omrani. "Protests Over High Food Prices Revive Opposition Parties. ” News Bank Access World News, April 17, 2008. Accessed on 10/04/2011. http://infoweb.newsbank.com.ezproxy.fiu.edu: p.1-3.

Obama, Barak. “A New Beginning.” June, 2009, www.whitehouse.gov. Accessed on 06/03/2012.

Oweidat, Nadia, Cheryl Benard, Dale Stahl, Walid Kildani, Edward O'Connell, and Audra K. Grant. "The Kefaya Movement A Case Study of a Grassroots Reform Initiative." Rand Corporation, 2008: p. 1-82.

Radwan, Amany. “Mubarak's Democracy Bombshell.” Time. Accessed on 5/29/2012. www.time.com: p. 1-3.

Rajiva, Lila. “The Torture-Go-Round.” Counterpunch, December 5, 2005. Accessed on 7/9/2012. http://www.counterpunch.org/2005/12/05/the-torturego-round.

Salem, Mahmoud. "Ranting's of the SandMonkey." www.sandmonkey.org/Archives, (2005-2011).

Sarte, Jean-Paul. Existentialism and Human Emotions. New York: Citadel Press. 1957.

Schwartz, Micael. "The Egyptian Uprising: The Mass Strike in the Time of Neoliberal Globalization.” New Labor Forum, 20 (3), Fall 2011: p. 33-43.

Sha'ban, Ahmed Baha' al-Din. “The Butterfly Effect: Kefaya-Past and Present.” Cairo, Kefaya Printings, 2006. 
Sharp, Gene. From Dictatorship to Democracy: A Conceptual Framework for Liberation. The Albert Einstein Institute. 1993.

Shehata, Dina. "The Fall of the Pharaoh: How Hosni Mubarak's Reign Came to an End". Foregin Affairs May/June 2011. Published by the Council on Foreign Relations. 2011.

Shishkin, Phillip. "American Revolutionary." Wall Street Journal. Accessed on 9/30/2011. http://online.wsj.com/article/SB122127204268531319.html?mod= Todays_us_nonsub_page: p. 1-5.

Shorbagy, Monar. "The Egyptian Movment for Change-Kefay: Redefining Politics in Egypt." Public Culture, 19:1. 2007: p. 175-196.

Skocpol, Theda. Social Revolutions in the Modern World. Cambridge: Cambridge University Press. 1994.

Skocpol, Theda and Ellen Kay Trimberger. "Revolutions: A Structural Analysis." Revolutions: Theoretical, Comparative, and Historical Studies. Ed. By Jack Goldstone. Wadsworth, 2008.

Society Online. Phillip N. Howard and Steve Jones Ed., California: Sage Publications. 2004.

Spot On. "Arab Crunch: Twitter Stats.” July, 2009. http://www.slideshare.net/ ArabCrunch/twitter-stats-in-the-arab-world-mena15-jul09-around-12266-users? p. 1-2.

Spot On. "Mid-East and North Africa Facebook and Twitter Demographics." May, 2010. Accessed on 6/10/2012. http://www.slideshare.net: p.1-14.

Sutter, John D. "The faces of Egypt's Revolution 2.0.” CNN. February 21, 2011. www.cnn.com: transcripts, p.1-8.

Svensson, Jakob. "Power and Participation in Digital Late Moderinity: Towards a Network Logic". Electronic Participation. Tambouris, Macintosh, and Bruijn Ed Netherlands: Springer Publishing. 2011.

Tweets From Tahrir. Edited by Nadia Idle and Alex Nunnis.OR Books. London: 2011.

Verba, Sidney, K. Schlozman and Henry E. Brady. Voice and Equality: civic voluntarism in American Politics. Cambridge: Harvard University Press. 1995.

Wheeler, Deborah L. "Egypt: Building an Information Society for International Development." Review of African Political Economy, No. 98. 2003: p.627-642. 
World Bank. accessed10/04/2011—URL: http://worldbank.org/ddp/htmljsp/view/NewReport.jsp?IS

www.harakmasria.org. "Kefaya:Who We Are”. Accessed 9/29/2011.

www.military.com. accessed on 6/12/2012

www.movements.org. accessed on 6/3/2012.

www.Orange.com. accessed on 12/18/2011.

www.quizegypt.gov.eg. Accessed on 6/10/2012.

Zhuo, Xiaolin, Barry Wellman, and Justine Yu. "Egypt: The First Internet Revolt?"

Peace Magazine. July/September 2011: p. 6-9. 